\title{
Charipinae fauna (Hymenoptera: Figitidae) from Asia with a description of 11 new species
}

Mar Ferrer-Suay ${ }^{1 *}$, Jesús Selfa ${ }^{2}$ and Juli Pujade-Villar ${ }^{1}$

\begin{abstract}
Background: The Charipinae from the Asian continent has been poorly studied. Previous to this study, 28 species of Charipinae had been mentioned: 19 of Alloxysta, 5 of Dilyta, 1 of Lobopterocharips, and 3 of Phaenoglyphis.

Results: The Charipinae fauna from Asia was studied. Eleven new species are described: Alloxysta asiatica Ferrer-Suay and Pujade-Villar sp. nov., Alloxysta nepalica Ferrer-Suay and Pujade-Villar sp. nov., Alloxysta nippona Ferrer-Suay and Pujade-Villar sp. nov., Alloxysta paretasmartinezi Ferrer-Suay and Pujade-Villar sp. nov., Alloxysta pilosa Ferrer-Suay and Pujade-Villar sp. nov., Alloxysta samurai Ferrer-Suay and Pujade-Villar sp. nov., Alloxysta sharkeyi Ferrer-Suay and Pujade-Villar sp. nov., Phaenoglyphis asiatica Ferrer-Suay and Pujade-Villar sp. nov., Phaenoglyphis chinensis Ferrer-Suay and Pujade-Villar sp. nov., Phaenoglyphis indica Ferrer-Suay and Pujade-Villar sp. nov., and Phaenoglyphis japonica Ferrer-Suay and Pujade-Villar sp. nov.

New records are given from the Eastern Palaearctic and Oriental regions for Alloxysta arcuata (Kieffer, 1902), Alloxysta brevis (Thomson, 1862), Alloxysta castanea (Hartig, 1841), Alloxysta consobrina (Zetterstedt, 1838), Alloxysta melanogaster (Hartig, 1840), Alloxysta obscurata (Hartig, 1840), Alloxysta pallidicornis (Curtis, 1838), Alloxysta pusilla (Kieffer, 1902), Alloxysta sawoniewiczi (Kierych, 1988), Alloxysta tscheki (Giraud, 1860), Alloxysta victrix (Westwood, 1833), Alloxysta xanthopa (Thomson, 1862), Phaenoglyphis longicornis (Hartig, 1840), Phaenoglyphis stricta (Thomson, 1877), Phaenoglyphis villosa (Hartig, 1841), and Phaenoglyphis xanthochroa Förster, 1869. Alloxysta ishizawai (Watanabe, 1950) is here synonymized with Phaenoglyphis ruficornis (Förster, 1869) and Alloxysta chinensis Fülöp \& Mikó, 2013 with A. sawoniewiczi. Alloxysta simplex (Watanabe, 1950) is considered as nomen dubium and Phaenoglyphis bangalorensis Kurian, 1953 is considered to be incertae sedis. A key to the identity of all of the Charipinae from Asia is given. All new species are illustrated.
\end{abstract}

Conclusions: The knowledge about the Charipinae from Asia has been greatly improved, with many new records established and new species described. Currently, there are 43 Charipinae species: 27 of Alloxysta, 5 of Dilyta, 1 of Lobopterocharips and 10 of Phaenoglyphis.

Keywords: Figitidae; Charipinae; Alloxysta; Phaenoglyphis; Asia

\section{Background}

The Charipinae is a very complicated group with 281 described species, of which 168 are considered valid (Ferrer-Suay et al. 2012). Members of the Charipinae are very small wasps, with a smooth and shiny body and little interspecific variability. They are widely distributed around the world. Charipines are biologically characterized to be hyperparasitoids of aphids and psyllids via the primary parasitoids Aphidiinae (Hymenoptera:

\footnotetext{
* Correspondence: mar.ferrer.suay@gmail.com

1 Departament de Biologia Animal, Facultat de Biologia, Universitat de Barcelona, Avda. Diagonal 645, Barcelona 08028, Spain

Full list of author information is available at the end of the article
}

Ichneumonoidea: Braconidae), Aphelininae (Hymenoptera: Chalcidoidea: Aphelinidae), and Encyrtidae (Hymenoptera: Chalcidoidea).

Alloxysta and Phaenoglyphis are the most abundant and widespread genera, with 111 and 31 valid species, respectively (Ferrer-Suay et al. 2012). Previous to this study, 28 species of Charipinae had been mentioned in Asia: Alloxysta arcuata (Kieffer, 1902), Alloxysta aurata Belizin, 1968, Alloxysta brevis (Thomson, 1862), Alloxysta capillata Belizin, 1962, Alloxysta castanea (Hartig, 1841), Alloxysta citripes (Thomson, 1862), Alloxysta consobrina (Zetterstedt, 1838), Alloxysta ishizawai (Watanabe, 1950), Alloxysta japonica (Ashmead, 1904), Alloxysta macrophadna (Hartig, 
1841), Alloxysta mara Paretas-Martínez and PujadeVillar, 2005, Alloxysta melanogaster (Hartig, 1840), Alloxysta pleuralis (Cameron, 1879), Alloxysta proxima Belizin, 1962, Alloxysta pusilla (Kieffer, 1902), Alloxysta ruficollis (Cameron, 1883), Alloxysta simplex (Watanabe, 1950), Alloxysta tscheki (Giraud, 1860), Alloxysta ullrichi (Giraud, 1860), Dilyta aleevae Pujade-Villar and Paretas-Martínez, 2011, Dilyta japonica ParetasMartínez and Ferrer-Suay, 2011, Dilyta sinica Ferrer-Suay and Paretas-Martínez, 2011, Dilyta longinqua ParetasMartínez and Pujade-Villar, 2011, Dilyta orientalis FerrerSuay and Paretas-Martínez, 2011, Lobopterocharips arreplegata Paretas-Martínez and Pujade-Villar, 2007, Phaenoglyphis bangalorensis Kurian, 1953, Phaenoglyphis insperatus Belizin 1973, and Phaenoglyphis villosa (Hartig 1841). From our study, 19 additional species were identified (11 of which are new species).

\section{Methods}

The studied material includes 168 specimens belonging to the Canadian National Collection of Insects (CNCI), Ottawa, Canada. This material was collected with malaise traps. Moreover, seven specimens from India were collected by sweeping. One Phaenoglyphis species is deposited in The Natural History Museum (BMNH), London. Holotypes of the new species and the majority of specimens are deposited in the CNCI. Some paratypes and specimens of previously known species are deposited in the Juli Pujade-Villar Collection at the Universitat de Barcelona (UB), Barcelona, Spain.

Specimens were studied using a stereomicroscope (Nikon SMZ-1, Barcelona, Spain) and an environmental scanning electron microscope (FEI Quanta 200 ESEM, Barcelona, Spain). A field-emission gun of the environmental scanning electron microscope was used for highresolution imaging without gold coating of the specimens. Morphological terms used were taken from ParetasMartínez et al. (2007a). Measurements and abbreviations include first and subsequent flagellomeres (F1 to F12). Metasomal tergal plates are expressed as T3 and T4. The width of the forewing radial cell was measured from the margin of the wing to the beginning of the Rs vein. Measures in antennal formulae are given by the length (width) from the scape to F4.

Additional abbreviations of institutions that appear in the text are as follows: National Museum of Victoria, Melbourne, Australia (MVMA); Lund Museum of Zoology, Lund, Sweden (MZLU); Muzeum i Instytutu Zoologii Polskiej Akademii Nauk, Warsaw, Poland (MZPW); Natural History Museum, Amiens, France (NHMA); Oxford University Museum of Natural History, Oxford, UK (UMNH); Museum für Naturkunde an der Humboldt-Universität, Berlin, Germany (ZMHB); and Zoologische Staatssammlung, München, Germany (ZSM).
Figures 1, 2, 3, 4, and 5 illustrate different morphological structures present in the Charipinae: forewing, apical club in the antenna, metasoma, and mesopleuron (Figure 1); proportions of the flagellomeres (Figure 2); pronotal carinae (Figure 3); propodeum (Figure 4); and radial cell (Figure 5). Figures $6,7,8,9,10,11,12,13,14,15$, and 16 illustrate the new species described herein.

\section{Results and discussion}

\section{Genus Alloxysta Förster, 1869}

Alloxysta Förster, 1869: 338 types. Species type: Xystus macrophadnus Hartig, 1841. Details of the common characters for all Alloxysta species are given below. The known Alloxysta species present in Asia are briefly described, and only the important useful characters, basically from the antenna and mesosoma, of the new species are presented to distinguish among them.

- Head. It is transversally ovate, smooth, and shiny, slightly wider than high in front view. It is with setae below, between, and above the toruli and with scattered setae on the vertex and many setae on the face. Transfacial line is 0.9 to 1.3 times the height of the compound eye. Malar space is 0.3 to 0.6 times the height of the compound eye.

- Antenna. All antennomeres are covered with sparse setae, filiform. Female: 13-segmented; male: 14segmented.

- Mesosoma. The pronotum is with scattered setae, with or without carinae. The mesoscutum is smooth and shiny, and round in dorsal view with sparse setae. The scutellum is smooth and shiny with scattered setae, which is usually more abundant on the apex of the scutellum. The propodeum has many setae, with or without carinae present.

- Forewing. It is longer than the body and is 1.4 to 1.8 times as long as the mesosoma and metasoma together. It is covered with dense pubescence; marginal setae are present.

- Metasoma. The anterior part is with an incomplete ring of setae, glabrous at the center, and wider laterally. The metasoma is smooth and shiny; T3 and $\mathrm{T} 4$ are clearly distinguished.

\section{Alloxysta arcuata (Kieffer, 1902)}

Allotria (Allotria) arcuata Kieffer, 1902: 12. Lectotype: $\mathrm{BMNH}$.

The diagnosis, material examined, and distribution are as follows:

- Diagnosis. In the Oriental region, A. arcuata is similar to $A$. sawoniewiczi, with both having a closed radial cell, pronotal and propodeal carinae, and F1 subequal to the pedicel. These species can be 

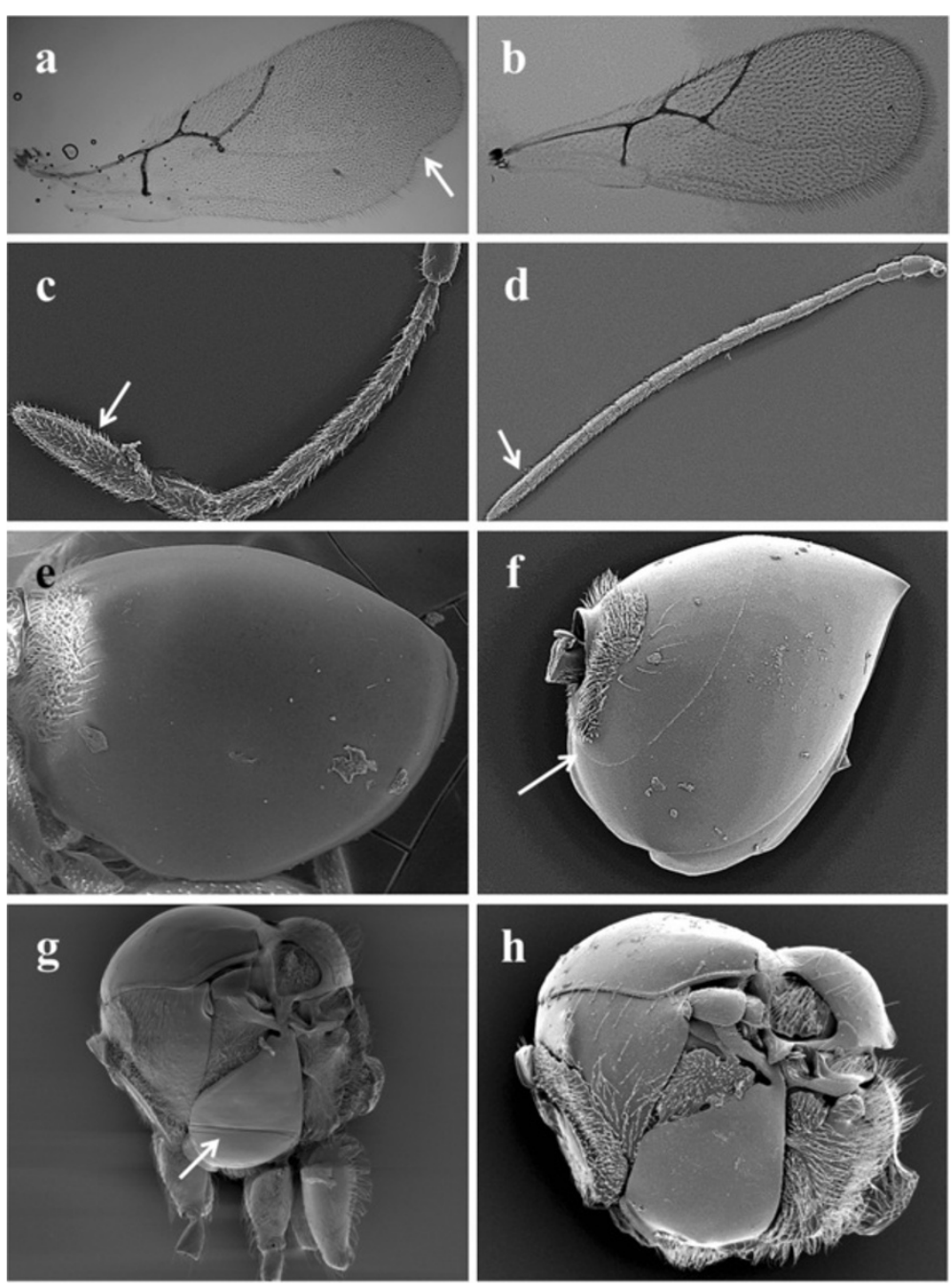

Figure 1 Morphological characters of the Charipinae. (a) Forewing of Lobopterocharips arreplegata; (b) forewing of Phaenoglyphis villosa; (c) antenna of Dilyta sp.; (d) antenna of P. americana; (e) metasoma of D. australafricana; (f) metasoma of Alloxysta halli; (g) mesopleuron of Phaenoglyphis sp.; (h) mesopleuron of A. halli.

distinguished by the following characters: antennae of $A$. arcuata are longer than the body length, while they are shorter in A. sawoniewiczi; in A. arcuata, rhinaria begin in F3 in females (Figure 2a) and F2 in males, while in A. sawoniewiczi, rhinaria begin in F5 in females (Figure $2 \mathrm{~g}$ ) and F4 in males; furthermore, propodeal carinae of $A$. arcuata form a plate with few setae on top and with slightly curved margins, while in A. sawoniewiczi, propodeal carinae are narrow and well-defined in the first half and are wide and forming a plate in the second half with sharp edges.

- Material examined. (4 $\delta^{\lambda}, 9$ q + ). C-465, Thailand: Chiang Mai, 70 km, SW, 3-12. V. 1990 M.T. Doi Inthanon Nat. Park, B.V. Brown, Oak for 1 Oे, 1 울 C-172, Taiwan: Wasche, 1,150 m, 3.V.1983, H. Townes Fit: 1 Oे; C-476, Taiwan: Taitung Hsien, Hsinkangshan above, Shang Kang, 800 m, 17-22.
IV.1998, A. Smetana and Lise Robilland: 1 ภ, 4 우우 C-477, Taiwan: Shan-Lin-Lhi (Nanton Hsien) 1,600 m, 16.V.1950, Fit and Pans, Primory for J. La Salle: 1 $\delta, 4$ 우. All materials are deposited in CNCI except $2 \hat{\jmath} \pi$ and 2 + 9 which are deposited in UB.

- Distribution. It was previously known to be from the Palaearctic and Neotropical regions. This species was previously mentioned to be from Asia, in Iran by Ferrer-Suay et al. (2013). New record is from Oriental region (Thailand, Taiwan).

\section{Alloxysta asiatica Ferrer-Suay and Pujade-Villar sp. nov.}

The diagnosis, type material, description, distribution, and etymology are as follows:

- Diagnosis. This species is easily differentiated from other Alloxysta species in the Oriental region by the 


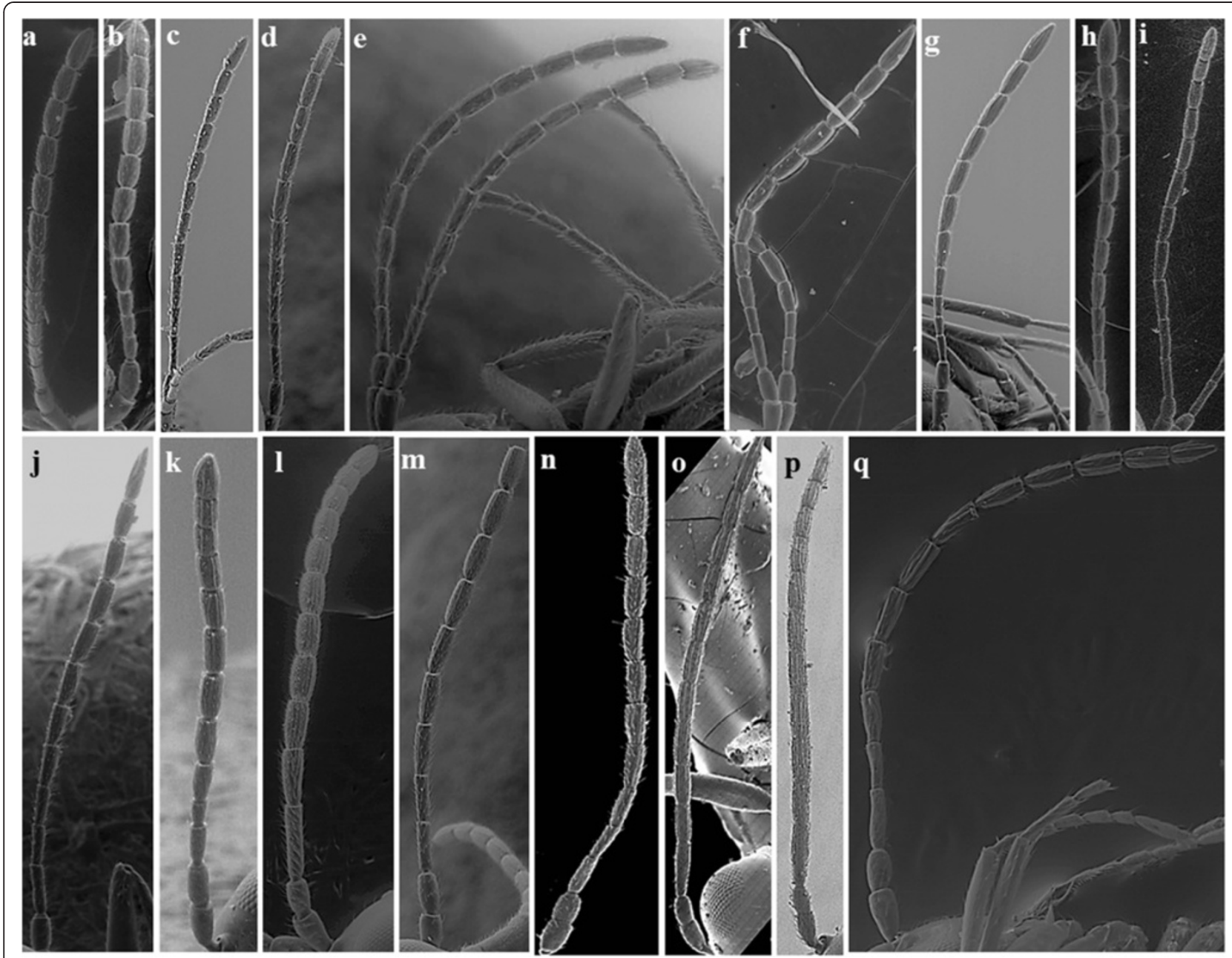

Figure 2 Antennae of Alloxysta species. (a) female of A. arcuata; (b) female of A. brevis; (c) female of A. castanea; (d) female of A. melanogaster; (e) female of A. obscurata; (f) female of A. pusilla; (g) female of A. sawoniewiczi; (h) female of A. tscheki; (i) female of $A$. victrix; (j) female of $A$. consobrina; (k) female of A. pleuralis; (I) female of A. pallidicornis; (m) female of A. xanthopa; (n) female of P. villosa; (o) female of A. longicornis; (p) female of $P$. stricta; and (q) male of $P$. xanthochroa.

partially open radial cell and having antennae shorter than the body length.

- Type material. (1 J, 1 ㅇ). Holotype of (deposited in CNCI): C-489, Thailand: Doi Inthanon, Chiang Mai 1,260 m, 31.I.I.-7.II.1989, T.V. Thormin M. T., $+18^{\circ} 34^{\prime} 47.92^{\prime},+98^{\circ} 28^{\prime} 59.88^{\prime}$. Paratype $\delta^{\prime}:$ C-400, Japan: Hokkaido, Tomuraushi Area, 13. VIII.1996, 500 m, L. Masner, S.S. J.08. Paratype $\widehat{\jmath}$ deposited in CNCI.

- Description. Length: female $1.0 \mathrm{~mm}$, male $0.8 \mathrm{~mm}$. Coloration: head, yellowish brown; mesosoma and metasoma, brown; scape, yellowish brown; pedicel to F3, dark yellow; F4 to F11, yellowish brown; legs and veins, yellowish brown. Antenna: female: F1 and F2 are smooth and thinner than the remaining flagellomeres; F3 to F11, with rhinaria and clubshaped. Antennal formula: 3.2 (2.5); 2.5 (2.2); 2.3 (1.2); 1.3 (1.2); 2.0 (1.5); 2.7 (1.9); F4 to F11 are subequal in length, width, and shape (Figure 6e). Male: F1 is smooth and thinner than the remaining flagellomeres; F2 to F12, with rhinaria and clubshaped. Antennal formula: 2.9 (1.6); 3.0 (1.9); 3.0 (1.0); F1 to F12, subequal in length, width, and shape (Figure 6d). Mesosoma: pronotum has scattered setae and two clearly visible long, thick carinae (Figure 6c). Apex of scutellum has thick carina (Figure 6g). Propodeum has many setae, two welldefined and slightly curved carinae, joining at the base (Figure 6f). Forewing has a partially open radial cell, 2.2 times as long as wide in females (Figure 6a) and 2.3 times in males (Figure 6b). R1 is short and curved; Rs is long and also curved.

- Distribution. Eastern Palaearctic: Japan. Oriental: Thailand.

- Etymology. The specific name refers to the continent where it was collected. 

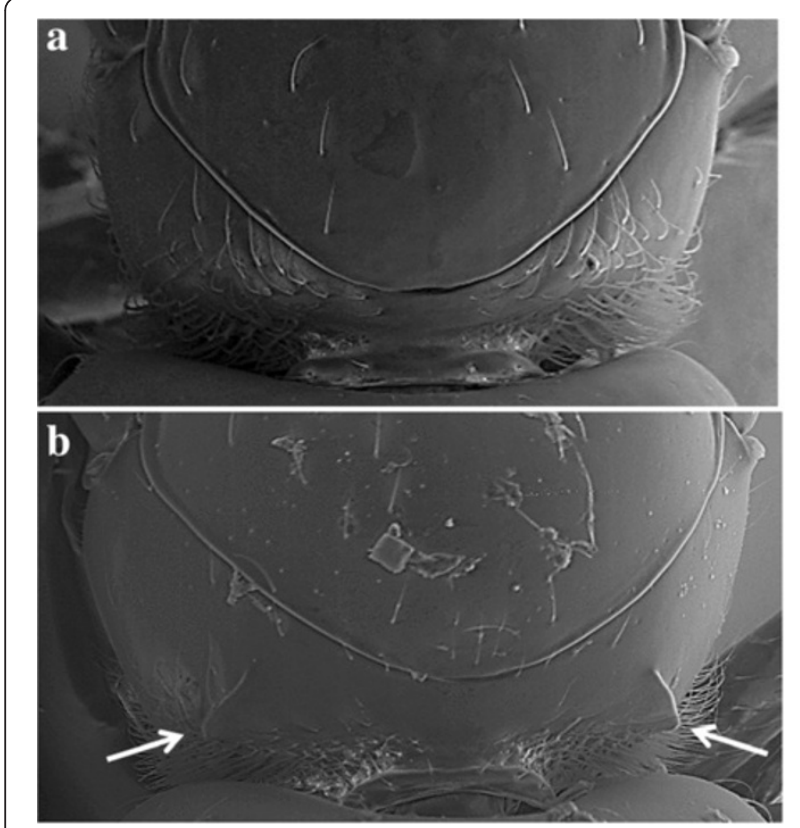

Figure 3 Pronotum (a) without carinae, Alloxysta brevis and (b) with carinae, Alloxysta sawoniewiczi.

\section{Alloxysta brevis (Thomson 1862)}

Allotria brevis Thomson 1862: 408. Lectotype: MZLU.

The diagnosis, material examined, and distribution are as follows:

- Diagnosis. A. brevis is similar to A. arcuata and A. sawoniewiczi because these three species have a closed radial cell and propodeal carinae present. These species can be distinguished by the following characters:

A. brevis has no pronotal carinae (Figure 3a), while

$A$. arcuata and $A$. sawoniewiczi have pronotal carinae (Figure $3 \mathrm{~b}$ ); F1 of $A$. brevis is shorter than the pedicel, and F1 $\sim \mathrm{F} 3$ are subequal (Figure $2 \mathrm{~b}$ ), while in $A$. arcuata and $A$. sawoniewiczi, flagellomeres have different proportions (Figure 2a, g).

- Material examined. (3 $\widehat{\delta}, 13$ 우). C-489, Thailand: Doi Inthanon, Chiang Mai 1,260 m, 31.I. I.-7.II.1989, T.V. Thormin M.T.: 1 9; C-379, Japan: Hokkaido, 20 km N, Akkeshi, Bekanbeushi, Marsh, 100 m, 15.VIII.1996, L. Masner, S.S. J-13: 1 o; C314, Japan: Honshu, Ibaraki pref. Tsuchiura, Sweep, 21.IX.1989, Marsh and Woods, M.J. Sharkey: 1 ㅇ; C-400, Japan: Hokkaido, Tomuraushi Area, 13. VIII.1996, 500 m, L. Masner, S.S. J.08: 1 o, 1 q; C546, Japan: Hokkaido, Sapporo, Jozankei, 27-28. IX.1989, 350 m, K. Maetox, M. Sharkey M.T.: 1 q; C-547, Japan: Hokkaido, Sapporo, Azzakei, 350 m, 10-21.VIII.1989, K. Mateos, M. Sharkey M.T.: 4 우; C-549, Japan: Hokkaido, Horoka 800 m, 5. VIII.1989, Sweep H.J. Sharkey: 1 q; Binodoxys indicus, Aphis craccivora, Vicia fabae, India, 02-I2007: 2 우; India: Uttar, Pradesh, Aligarh, 22.VII.1983, S.S. Islam: $2 \widehat{\delta}, 1$ ㅇ. All materials are deposited in CNCI except 5 우 which are deposited in UB.

- Distribution. Species was previously known to be from the Palaearctic and Neotropical regions. This species was previously mentioned to be from Asia, in Japan by Takada and Nakamura (2010) and in Iran by Lotfalizadeh (2002a). New record is from the Oriental region (India, Thailand).

\section{Alloxysta castanea (Hartig, 1841)}

Xystus castaneus Hartig, 1841: 352. Lectotype: ZSM.

The diagnosis, material examined, and distribution are as follows:

- Diagnosis. A. castanea is similar to A. melanogaster and $A$. obscurata, all of them have a partially open radial cell, and pronotal carinae are present. These species can be distinguished by the following characters: in A. castanea, rhinaria begin in F4 (Figure 2c), while in $A$. melanogaster, rhinaria begin in F3 in both male and female (Figure 2d), and in F3 in females and F4 in males of $A$. obscurata
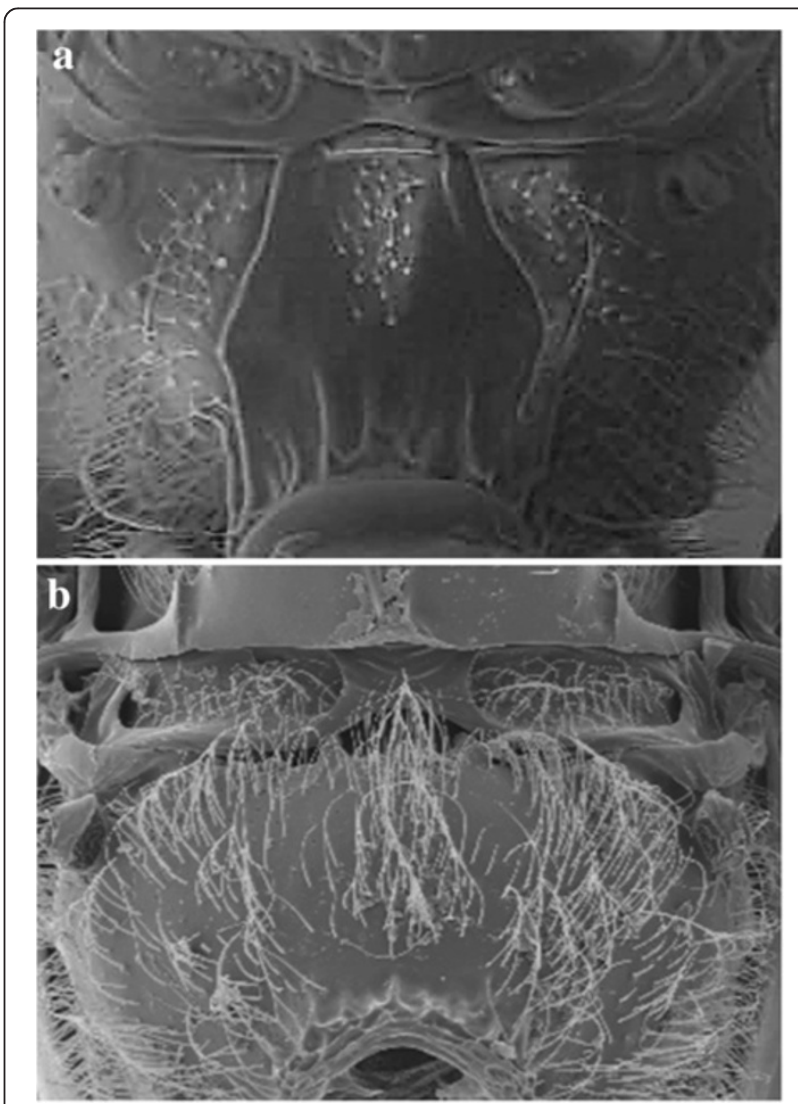

Figure 4 Propodeum (a) with carinae, Alloxysta pusilla and (b) without carinae, Alloxysta victrix. 


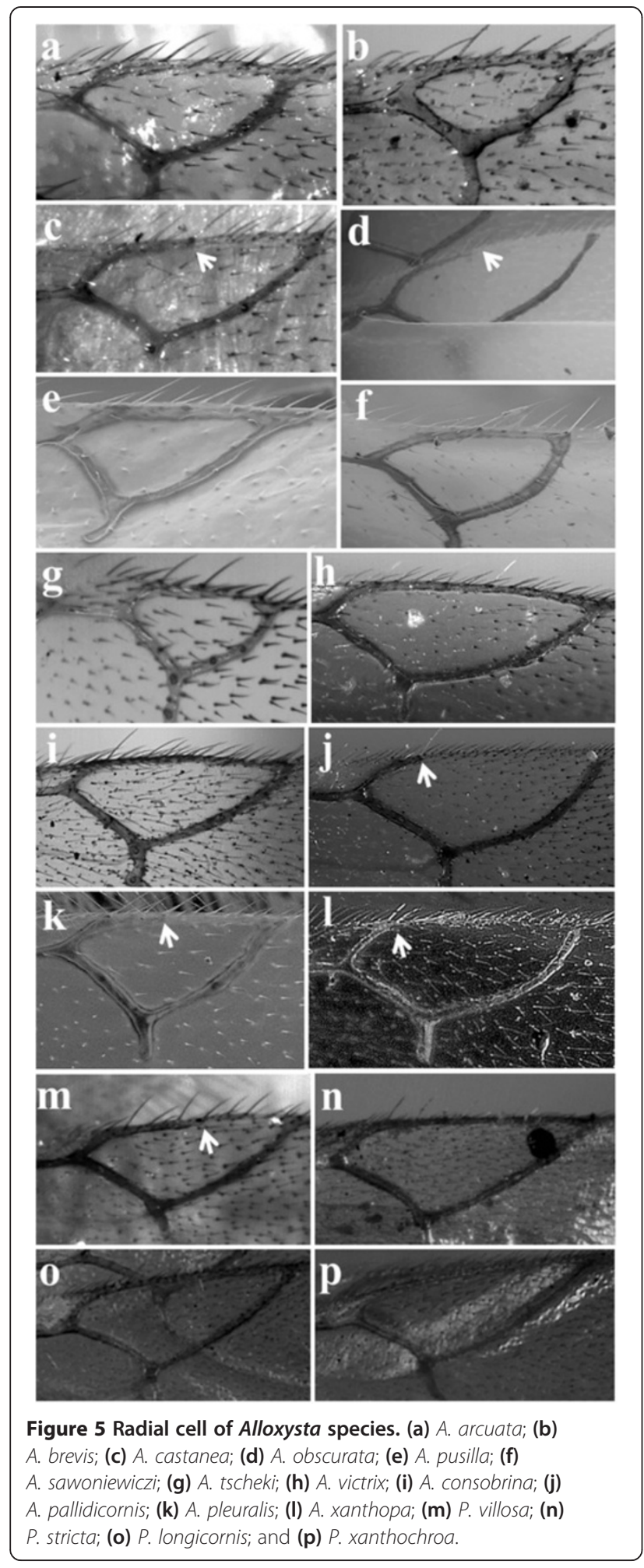

(Figure 2e); F1 of females of $A$. castanea is longer than the pedicel and F2, F2 is subequal to F3 (Figure 2c), while in females of $A$. melanogaster, pedicel to F3 are subequal (Figure 2d), and in females of $A$. obscurata, F1 is longer than the pedicel and F2, and F2 is shorter than F3

(Figure 2e); radial cell of $A$. castanea is 2.4 times as long and as wide (Figure 5c), 2.0 times in $A$. melanogaster, and 2.7 times in $A$. obscurata (Figure 5d).

- Material examined. (4 ふふત, 22 우). C-516, South Korea: Mt. Sudo San, 400 m. 23.VIII.1990, K. Tinagishi S.J.: 1 +; C-459, Malaysia: Selanyor, 1,750 m, 28.VI.1990, J. Heraty: 1 §̊; C-553, Taiwan: Nantou, Lienhanatge 750 m, 20.II-18.IV.1991, C.H. Starr and C.S. Liu: 9 우 C-444, Japan: Kumamoto, M.T. Kurotake, 900 m, 14.V.1989, M. Sharkey sweep: 1 đ̊, 2 qo ; C-390, Japan: Iwate, Matsukusa, 600 m, 21.VI.1989, Sweep M. J. Sharkey: 1 ; C-550, Japan: Akita, Ohdate, linba 27.IX.1992, K. Yamagishi: 1 q; C-543, Japan: Hokkaido, Hidaka Mts. below Pyo tan 500, 14.VIII.1996, L. Masner, S.S.J-12: 1 đ;; C-549, Japan: Hokkaido, Horoka 800 m, 5.VIII.1989, Sweep H.J. Sharkey: 5 우; C-477, Taiwan: Shan-LinLhi (Nanton Hsien) 1,600 m, 16.V.1950, Fit and Pans, Primory for J. La Salle: 2 q, ; Nepal, Ktmd. Pulchauki 7300', 4-7. VIII.1967, Mal. Tr., Can. Exp.: 1 웅 Niizamachi, Saitama, Japan, 15.IV.1960, T.

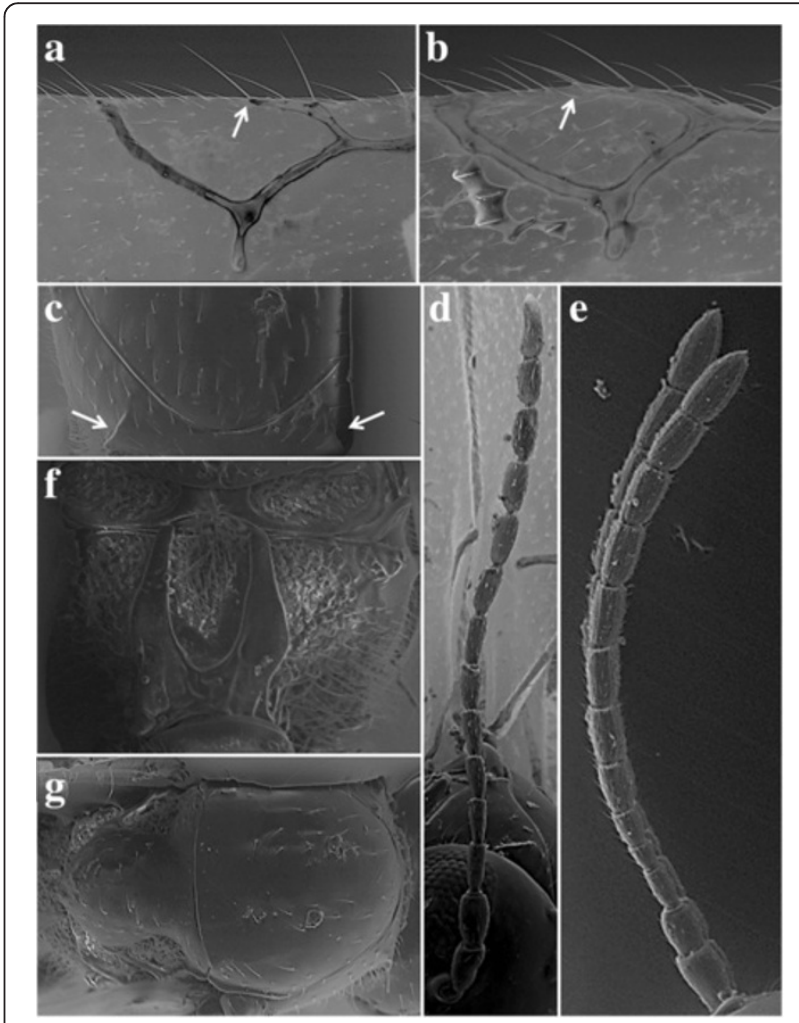

Figure 6 Alloxysta asiatica Ferrer-Suay and Pujade-Villar sp. nov. (a) Radial cell, female; (b) radial cell, male; (c) pronotum; (e) antennae, male; (e) antennae, female; (f) propodeum; and (g) mesoscutum. 

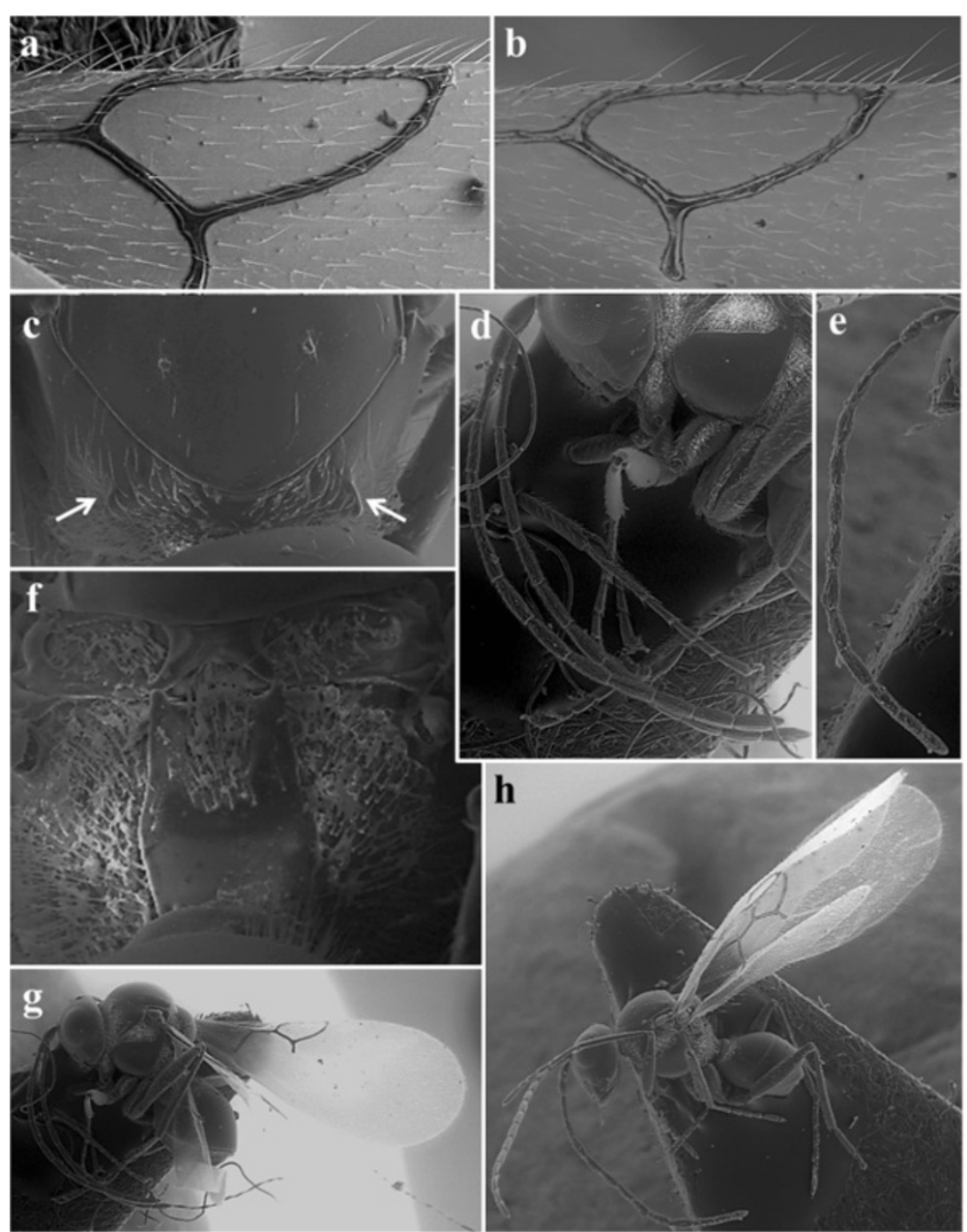

Figure 7 Alloxysta nepalica Ferrer-Suay and Pujade-Villar sp. nov. (a) Radial cell, female; (b) radial cell, male; (c) pronotum; (d) antennae, female; (e) antennae, male; (f) propodeum; (g) body, female; and (h) body, male.

Hayasaka: 1 $\delta$. All materials are deposited in $\mathrm{CNCI}$, except for 1 t and 8 우 which are deposited in UB.

- Distribution. Species was previously known to be from the Palaearctic and Neotropical regions. This species was previously mentioned to be from Asia, in Iran by Ferrer-Suay et al. (2013). New record is from Japan and South Korea. There is a new record for the Oriental region (Malaysia, Nepal, Taiwan).

\section{Alloxysta consobrina (Zetterstedt, 1838)}

Cynips consobrina Zetterstedt, 1838: 352. Lectotype: MZLU.

The diagnosis, material examined, and distribution are as follows:

- Diagnosis. This species is very similar to A. victrix but can be differentiated by proportions between flagellomeres: F2 is longer than F3 and F3 shorter than F4 in A. consobrina, but F2 to F4 are subequal in length in A. victrix (Figure 2i); size of radial cell is 2.7 times as long as wide in $A$. consobrina while 3.0 times in A. victrix (Figure 5h); propodeum is completely covered with dense setae in A. consobrina, but propodeum is lacking setae in the longitudinal area where carinae are present in other Charipinae in A. victrix (Figure 4b).

- Material examined. (1 +). Lysiphlebia mirzai, Aphis gossypii, India, Rajori, 02-I-2007 are deposited in UB.

- Distribution. Cosmopolitan. This species was previously mentioned to be from Asia, in Iran by Lotfalizadeh (2002b) and Lotfalizadeh and van Veen (2004). New record is from the Oriental region (India).

\section{Alloxysta melanogaster (Hartig, 1840)}

Xystus melanogaster Hartig, 1840: 200. Lectotype: ZSM.

The diagnosis, material examined, and distribution are as follows: 

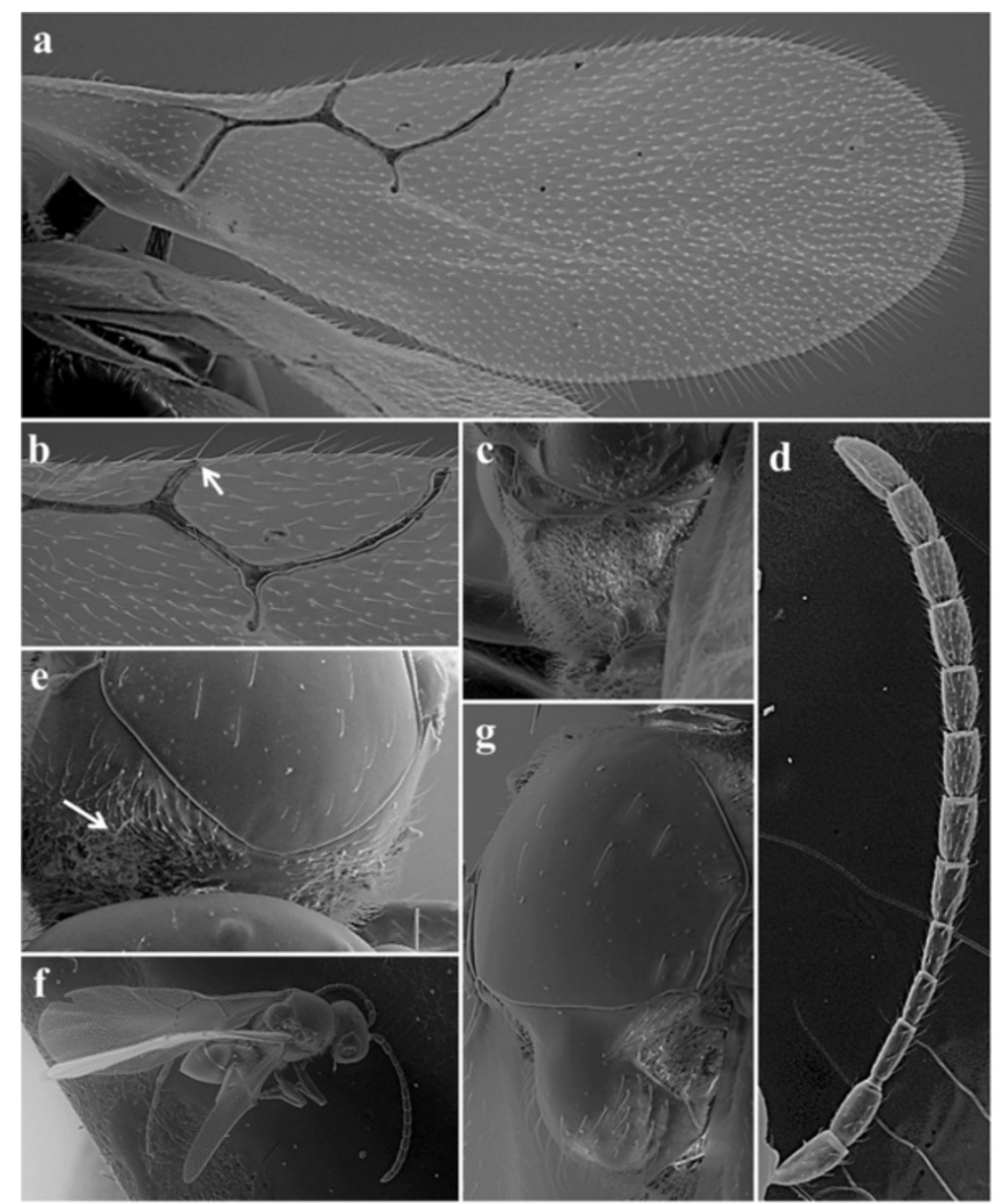

Figure 8 Alloxysta nippona Ferrer-Suay and Pujade-Villar sp. nov. (a) Forewing, (b) radial cell, (c) propodeum, (d) antenna, (e) pronotum, (f) body, and (g) mesoscutum.

- Diagnosis: A. melanogaster is similar to A. castanea and A. obscurata, all of them have a partially open radial cell, and pronotal carinae are present. These species can be distinguished by the following characters: in A. melanogaster, rhinaria begin in F3 (Figure 2d), while in A. castanea, rhinaria begin in $\mathrm{F} 4$ (Figure 2c), and in A. obscurata, rhinaria begin in F3 in females and F4 in males (Figure 2e); the female of A. melanogaster is with subequal pedicel to F3 (Figure 2e), while in female of $A$. castanea, F1 is longer than the pedicel and F2, F2 is subequal to F3 (Figure 2c), and in female of A. obscurata, F1 is longer than pedicel and F2, F2 is shorter than F3 (Figure 2e); and radial cell of $A$. melanogaster is 2.0 times as long as wide, 2.4 times in A. castanea (Figure 5c), and 2.7 times in A. obscurata (Figure 5d).

- Material examined. (2 $\widehat{\partial}, 34$ 우). C-410, Thailand: Doi Inthanon, Nat. Park, 70 km. SW. 1,250 m, Chiang Mai, 31.I-7.II.1989, T.V. Thormin lg: 3 우우; C-172, Taiwan: Wasche, 1,150 m, 3. V.1983, H. Townes Fit: 2 우우 C-409, Taiwan:
Nanton Hsien Washe, rd to Green Lake, 1,100 m, 27.V.1990, J. Hevaty: 1 dं; C-402, Taiwan: Nanton Mei Jang, 2,100 m (well forest), 19.IX-16.XII.1990, C.S. Lin: 1 ; C -17, Taiwan: Taipes Jang mishan Site, 18-28.IV.1991, YPT, H.Y. Wang: 1 क; C-553, Taiwan: Nantou, Lienhanatge $750 \mathrm{~m}, 20 . \mathrm{II}-18$. IV.1991, C.H. Starr and C.S. Liu: 3 우 C-458, Taiwan: Nashe, 2.IV.1983, 1150, H. Townes, Fit.: 2 우; C-476, Taiwan: Taitung Hsien, Hsinkangshan above, Shang Kang, 800 m, 17-22.IV.1998, A. Smetana and Lise Robilland: 1 + ; C-383, Japan: Kyushu, 700 m, Fukuoka, Mt. Hiko, 4-11.IX.1989, M.T., K. Takeno and M. Sharkey: 2 우; C-185, Japan: Fukuoka, Mt. Hiko, 700 m, 28.IV-8-10. V.1989, sweep M.J. Sharkey: 1 क; C-546, Japan: Hokkaido, Sapporo, Jozankei, 27-28.IX.1989, 350 m, K. Maetox, M. Sharkey M.T.: 2 q + ; C-477, Taiwan: Shan-Lin-Lhi (Nanton Hsien) 1,600 m, 16.V.1950, Fit and Pans, Primory for J. La Salle: 1 o , 16 우. All materials are deposited in CNCI except $1 \hat{\delta}$ and 10 우 which are deposited in UB. 


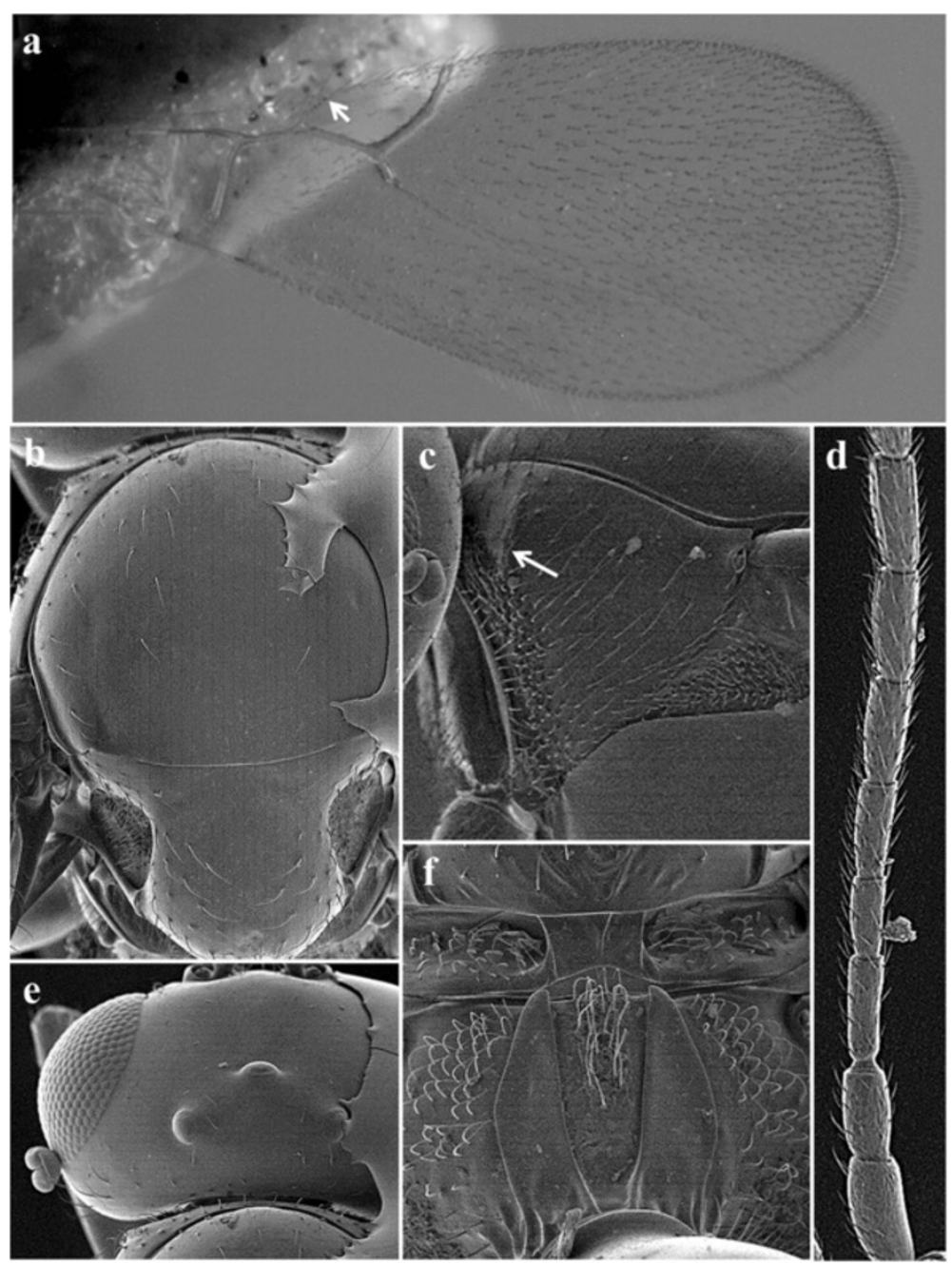

Figure 9 Alloxysta paretasmartinezi Ferrer-Suay and Pujade-Villar sp. nov. (a) Forewing, (b) mesoscutum, (c) pronotum, (d) antennae, (e) head in dorsal view, and (f) propodeum.

- Distribution. Species was previously known to be from the Palaearctic region. This species was previously mentioned to be from Asia, in Iran by Ferrer-Suay et al. (2013). New record from Japan. New record for the Oriental region (Thailand, Taiwan).

\section{Alloxysta nepalica Ferrer-Suay and Pujade-Villar sp. nov.}

The diagnosis, type material, description, distribution, and etymology are as follows:

- Diagnosis. A. nepalica sp. nov. is similar to A. pusilla by having a closed radial cell, pronotal and propodeal carinae, and F1 is longer than pedicel. $A$. nepalica sp. nov. can be distinguished by the radial cell size: female of $A$. nepalica sp. nov. is with a radial cell 2.9 times as long as wide (Figure 7a), 2.7 times in males (Figure $7 \mathrm{~b}$ ), while in A. pusilla, radial cell is 2.1 times in females (Figure 5e) and 2.4 times in males, and male of $A$. nepalica is without curved flagellomeres (Figure 7e), while the male of $A$. pusilla is with slightly curved F1 to F3.

- Type material. $(9 \hat{\jmath} \widehat{\partial}, 4$ 우). Holotype $\widehat{\partial}$ (deposited in CNCI): C-474, Nepal: Latha Manang, W.

Bagarchap 2,350 m, 24.IX.1983, A. Smetana, $+28^{\circ} 32^{\prime}$ $23.62^{\prime},+84^{\circ} 20^{\prime} 16.52^{\prime}$. Paratypes $\left(8 \jmath^{\jmath}{ }^{\jmath}, 4\right.$ 우우): C-474, Nepal: Latha Manang, W. Bagarchap 2,350 m, 24.

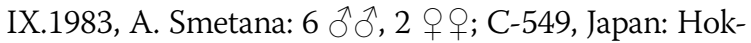
kaido, Horoka 800 m, 5.VIII.1989, Sweep H.J. sharkey:

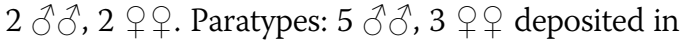
$\mathrm{CNCI}$, and $3 \hat{\delta} \bar{o}$ and $1 \%$ deposited in UB.

- Description: Length: female $1.5 \mathrm{~mm}$, male 1.1 to $1.5 \mathrm{~mm}$. Coloration: head yellowish brown; mesosoma and metasoma, dark brown; antennae, yellow and darkening towards apical part; legs and 


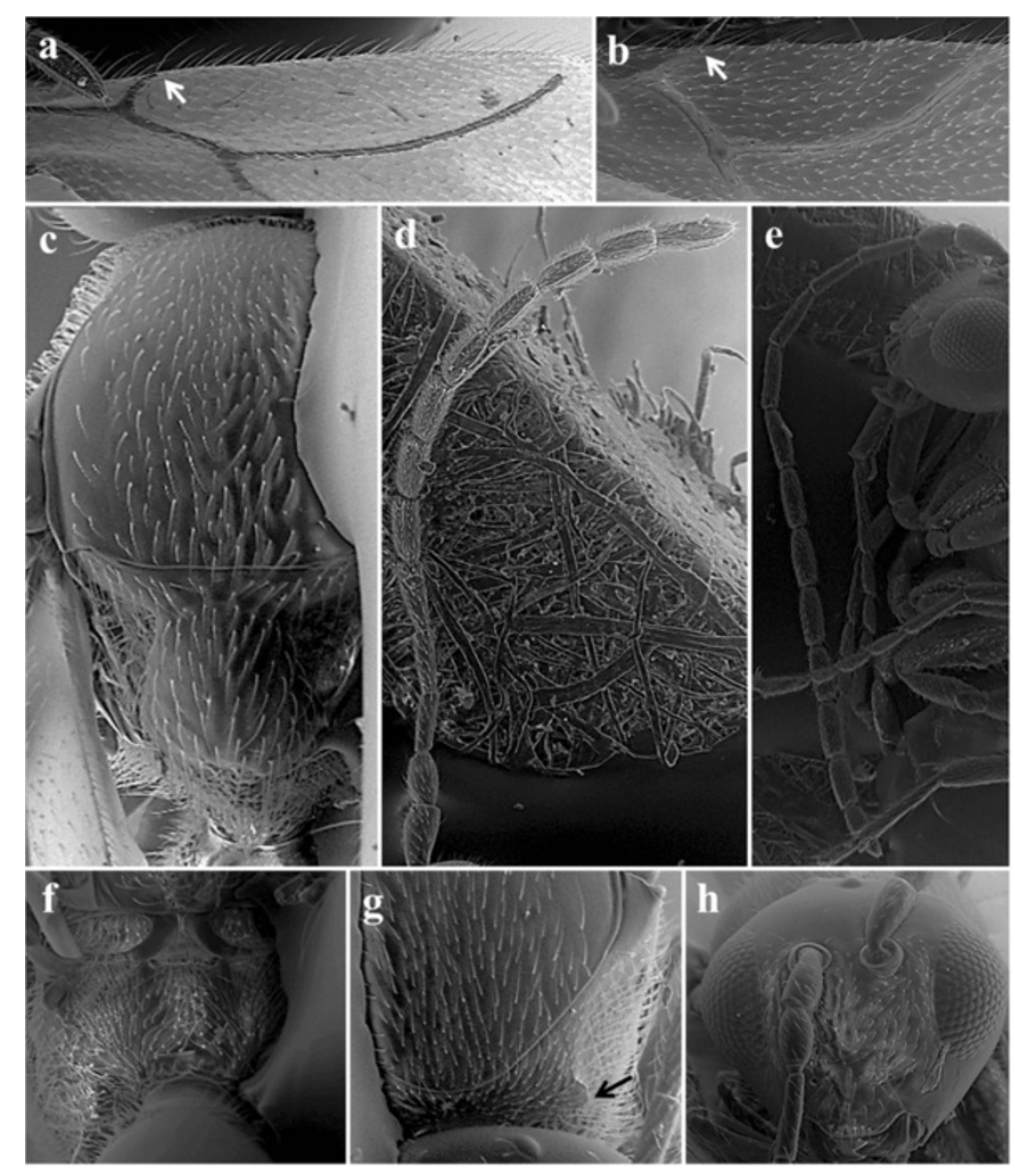

Figure 10 Alloxysta pilosa Ferrer-Suay and Pujade-Villar sp. nov. (a) Radial cell, female; (b) radial cell, male; (c) mesoscutum; (d) antenna, female; (e) antenna, male; (f) propodeum; (g) pronotum; and (h) head.

veins, yellowish brown. Antenna: female: F1 and F2 are smooth and thinner than remaining flagellomeres; F3 to F11, with rhinaria and clubshaped. Antennal formula: 2.5 (1.4); 2.5 (1.1); 4.0 (0.6); 3.4 (0.7); 3.5 (1.0); 3.7 (1.0); F4 F11 are subequal in length, width, and shape (Figure $7 \mathrm{~d}$ ). Male: F1 is smooth and thinner than the remaining flagellomeres; F2 to F12, with rhinaria and club-shaped. Antennal formula: 3.0 (1.2); 2.3 (1.2); 3.8 (0.9); F1 to F12 are subequal in length (Figure 7e). Mesosoma: pronotum has sparse setae, less setae on posterodorsal margins, and two thick carinae clearly visible (Figure 7c). Propodeum has many setae and two carinae forming a plate with setae on the central upper area (Figure 7f). Forewing has a closed radial cell, 2.7 times as long as wide in males (Figure 7b), 2.9 times in females (Figure 7a). R1 is short and slightly curved; Rs is long and curved.

- Distribution. Eastern Palaearctic: Japan, Nepal.

- Etymology. Specific name refers to the country where the holotype was collected.

\section{Alloxysta nippona Ferrer-Suay and Pujade-Villar sp. nov.}

The diagnosis, type material, description, distribution, and etymology are as follows:

- Diagnosis. A. nippona sp. nov. differs from other Alloxysta species present in the Oriental region by an open radial cell lacking propodeal carinae (Figure 8c). A. pilosa also lacks propodeal carinae, but the body of A. nippona sp. nov. is not entirely covered by abundant setae, and its radial cell is not as large.

- Type material. (1 9 ). Holotype $q$ (deposited in CNCI): C-543, Japan: Hokkaido, Hidaka Mts. below Pyo $\tan 500,14$. VIII.1996, L. Masner, S.S.J-12, $+42^{\circ}$ $29^{\prime} 13.33^{\prime},+142^{\circ} 4^{\prime} 17.11^{\prime}$.

- Description. Length: female $0.8 \mathrm{~mm}$, male unknown. Coloration: head, mesosoma, and metasoma, brown; scape, pedicel, and F1 to F3, yellow; F4 to F11, yellowish brown; legs, dark yellow; veins, yellowish brown. Antenna: female: F1 to F3, smooth and thinner than remaining flagellomeres; F4 to F11, with rhinaria and club-shaped. Antennal formula: 3.5 (1.7); 3.0 (1.6); 3.0 (1.0); 2.5 (1.0); 2.5 (1.0); 2.9 


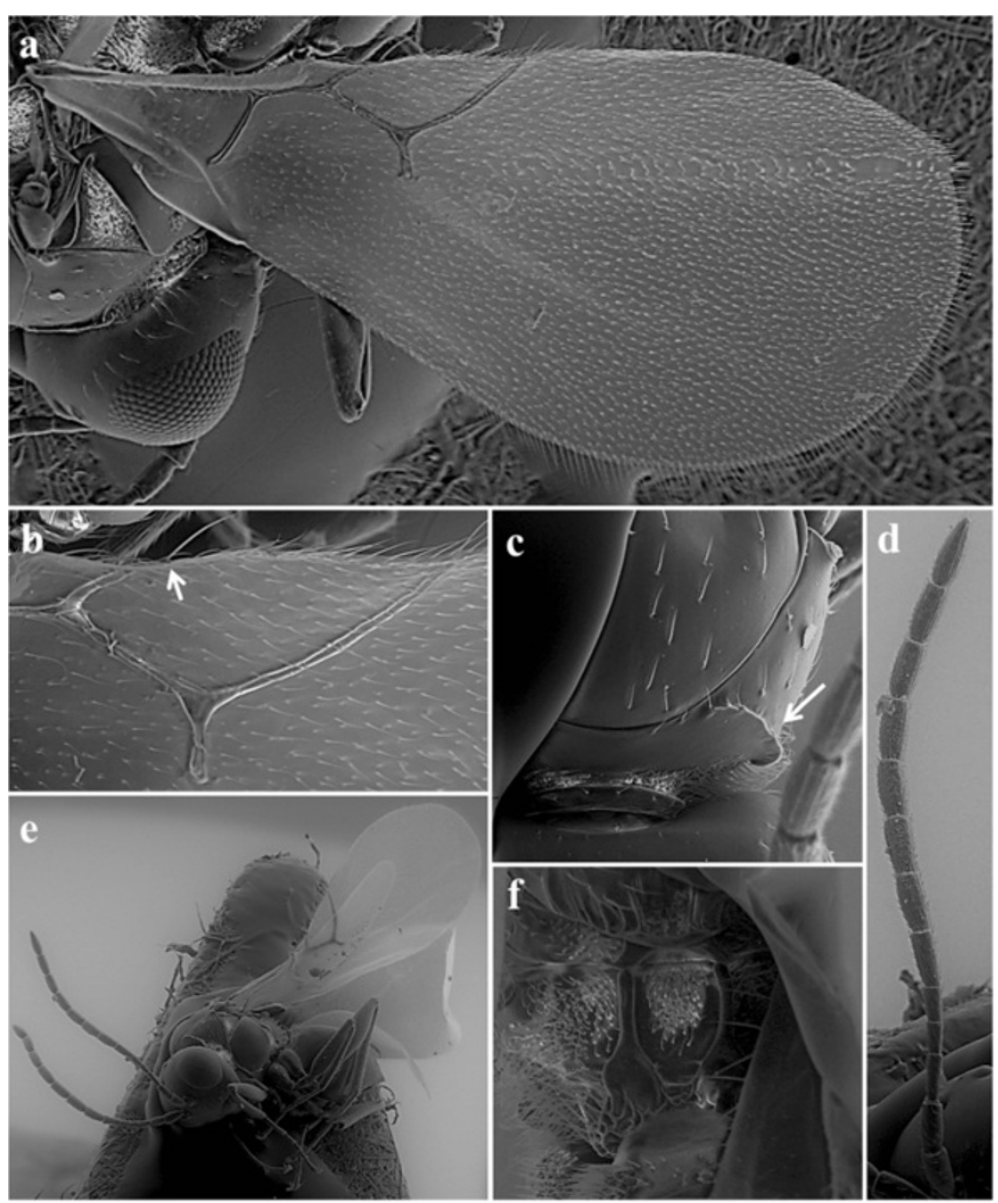

Figure 11 Alloxysta samurai Ferrer-Suay and Pujade-Villar sp. nov. (a) Forewing, (b) radial cell, (c) pronotum, (d) antenna, (e) body, and (f) propodeum.

(1.5); F4 to F11 are subequal in length, width, and shape (Figure 8d). Mesosoma: pronotum has many setae; two carinae are present but sometimes difficult to see under pubescence (Figure 8e). Propodeum is entirely covered with abundant setae; no carinae are present (Figure 8c). Forewing has open radial cell, 2.3 times as long as wide. R1 is short and slightly curved; Rs is long and curved, not reaching costal margin (Figure 8a, b).

- Distribution. Eastern Palaearctic: Japan.

- Etymology. Specific name refers to the country where it was collected.

\section{Alloxysta obscurata (Hartig, 1840)}

Xystus obscuratus Hartig, 1840: 200. Lectotype: ZSM.

The diagnosis, material examined, short description, and distribution are as follows:

- Diagnosis. A. obscurata is similar to A. castanea and A. melanogaster by having a partially open radial cell, and pronotal carinae are present. These species can be distinguished by the following characters: propodeal carinae is absent in $A$. obscurata while present in $A$. castanea and $A$. melanogaster; in $A$. obscurata, rhinaria begin in F3 in females and F4 in males (Figure 2e), while in A. castanea, rhinaria begin in F4 (Figure 2c), and in A. melanogaster, rhinaria begin in F3 (Figure 2d); female of $A$. obscurata has longer F1 than pedicel and F2, F2 is shorter than F3 (Figure 2e), while in the female of $A$. castanea, F1 is longer than pedicel and F2, F2 is subequal to F3 (Figure 2c), and in female of $A$. melanogaster, pedicel to F3 is subequal (Figure 2d); and radial cell of $A$. obscurata is 2.7 times as long as wide (Figure $5 \mathrm{~d}$ ), 2.4 times in $A$. castanea (Figure 5c), and 2.0 times in A. melanogaster.

- Material examined. (2 우). C-535, Japan: Hokkaido, Bibai Koshunai, 200 to 250 m, 3.VIII.1989, M. Sharkey, Sweep: 1 + ; C-547, Japan: Hokkaido, Sapporo, Azzakei, 350 m, 10-21.VIII.1989, K. Mateos, M. Sharkey M.T.: 1 ․ 1 is deposited in $\mathrm{CNCI}$, and $1+$ is deposited in UB. 

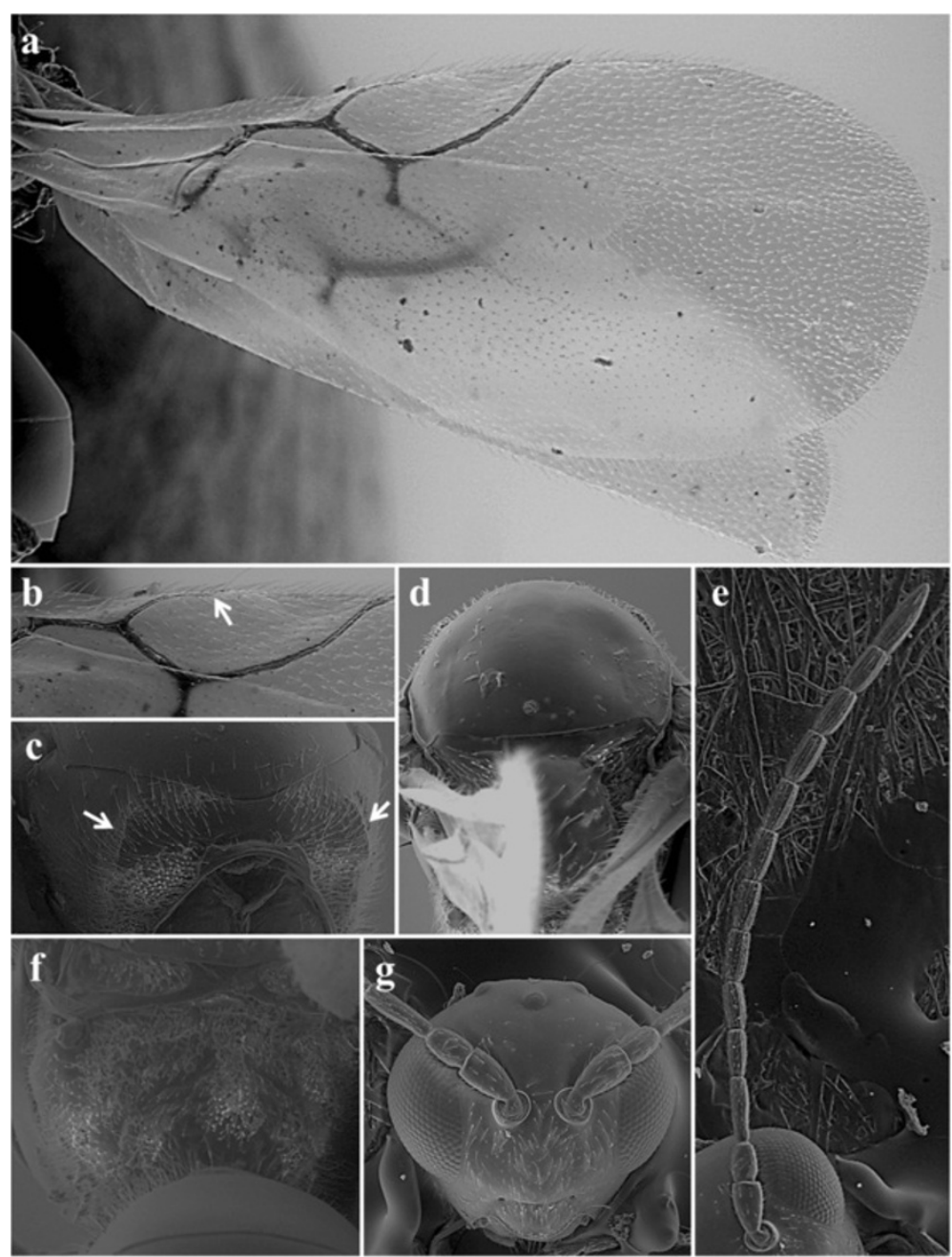

Figure 12 Alloxysta sharkeyi Ferrer-Suay and Pujade-Villar sp. nov. (a) Forewing, (b) radial cell, (c) pronotum, (d) mesoscutum, (e) antenna, (f) propodeum, and (g) head.

- Short description. Head, mesosoma, and metasoma, dark brown; scape, pedicel, F1, and F2, dark yellow, F3 to F12 yellowish brown; legs and veins, yellowish brown. In females, F1 and F2, smooth and thinner than remaining flagellomeres; F3 F11, with rhinaria and club-shaped; F1 is longer than the pedicel and F2, F2 is subequal to F3, and F3 is shorter than F4 (Figure 2e). In males, F1 to F3 are smooth and thinner than the remaining flagellomeres; F4 to F12, with rhinaria and club-shaped; F2 is slightly curved; F1 is longer than the pedicel and F2, F2 is longer than F3, and F3 is longer than F4. Pronotum is covered by setae with two clearly visible long, thick carinae. Propodeum is densely covered with long setae without carinae. Forewing is longer than the body; radial cell is partially open, 2.7 times as long as wide (Figure 5d).
- Distribution. Species is known to be from the Holarctic region. There is a new record from Japan.

\section{Alloxysta pallidicornis (Curtis, 1838)}

Cynips pallidicornis Curtis, 1838: 688 (April 1). Lectotype: MVMA.

The diagnosis, material examined, short description, and distribution are as follows:

- Diagnosis. A. pallidicornis is easily differentiated from all other Alloxysta species present in Asia by its combination of features: a completely open radial cell, pronotal and propodeal carinae are present, well defined and separated by setae in the first half and forming a plate in the last half, beginning of rhinaria in F2, and F1 with very big length/width relation. 


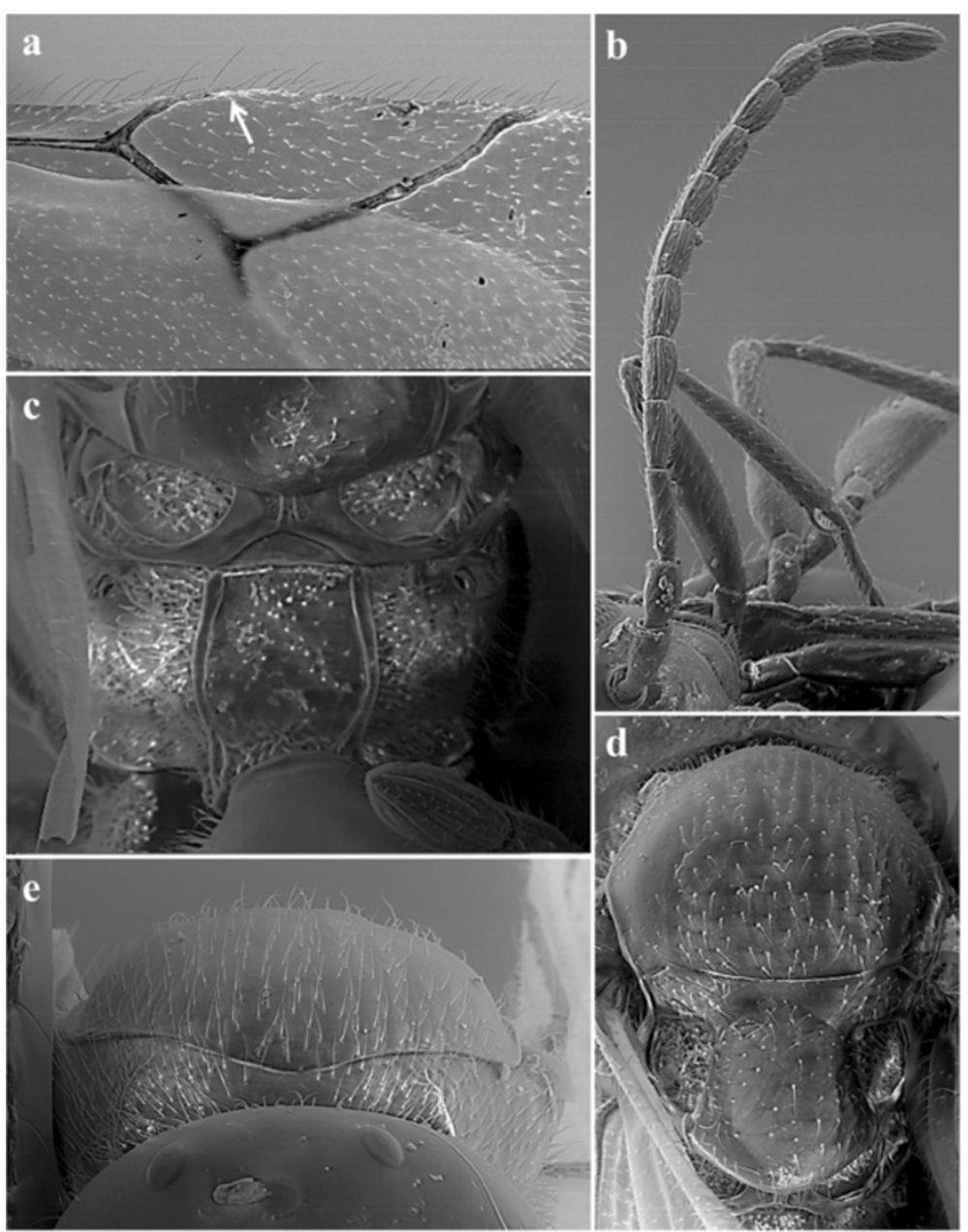

Figure 13 Phaenoglyphis asiatica Ferrer-Suay and Pujade-Villar sp. nov. (a) Radial cell, (b) antennae, (c) propodeum, (d) mesoscutum, and (e) pronotum.

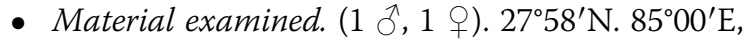
Mal.tr.1, 11, 100', 11-17 May 1967, Can.Nepal. Exped.: $1 \partial^{\prime} ; 27^{\circ} 58^{\prime}$ N. $85^{\circ} 00^{\prime}$ E, Mal.tr.2, 11, 200', 18-22 May 1967, Can.Nepal.Exped.": 1 q. (Deposited in $\mathrm{CNCI}$.

- Short description. Head, yellowish brown; mesosoma and metasoma, dark brown; scape, brown; pedicel and all flagellomeres, yellowish brown; legs and veins, yellowish brown. In females, F1 is smooth and thinner than the remaining flagellomeres, F2 to F11, with rhinaria and club-shaped; F1 is longer than the pedicel and F2, and F2 to F4 are subequal in length (Figure 2l). In males, F1 to F12, with rhinaria and club-shaped; F2 is slightly curved; F1 is longer than the pedicel and F2, F2 is slightly longer than F3, F3 and F4 are subequal in length. Pronotum is entirely covered by setae, with two clearly visible long, thick carinae. Propodeum is covered with abundant pubescence, with well-defined carinae and separated by setae in the first half and forming a plate in the second half. Forewing is longer than the body; radial cell is open, 2.6 times as long as wide (Figure 5j).

- Distribution. Species was previously known to be from the Holarctic region. There is a new record for the Oriental region (Nepal).

\section{Alloxysta paretasmartinezi Ferrer-Suay and Pujade-Villar} sp. nov.

The diagnosis, type material, description, distribution, and etymology are as follows:

- Diagnosis: This species is similar to A. samurai sp. nov. in having an open radial cell, and pronotal and propodeal carinae are present. They can be distinguished by the following: in $A$. paretasmartinezi sp. nov., rhinaria begin in F3 (Figure 9d), while in A. samurai sp. nov., rhinaria begin in F4 (Figure 11d); F1 of $A$. paretasmartinezi 

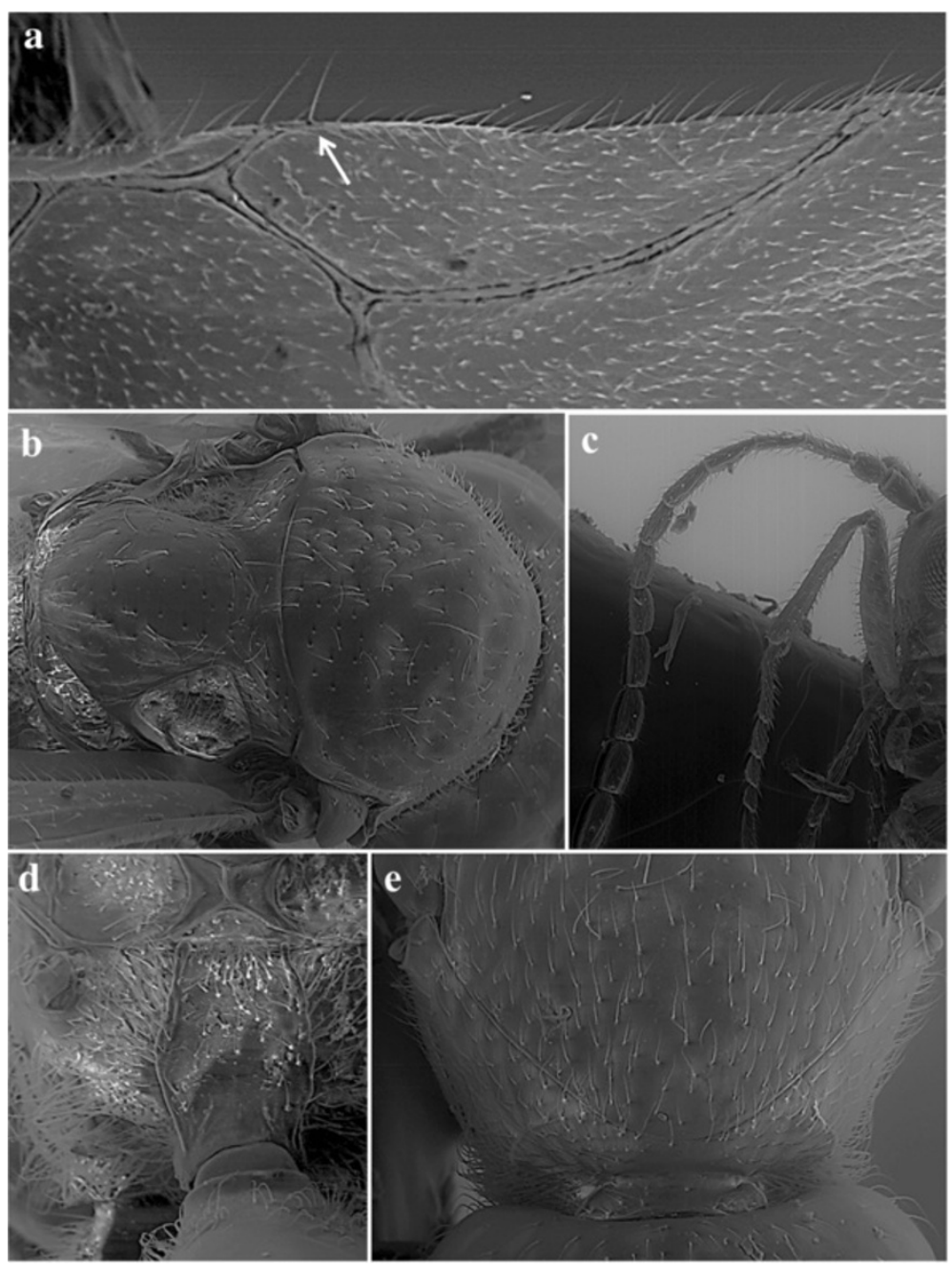

Figure 14 Phaenoglyphis chinensis Ferrer-Suay and Pujade-Villar sp. nov. (a) Radial cell, (b) mesoscutum, (c) antenna, (d) propodeum, and (e) pronotum.

sp. nov. is longer than pedicel (Figure 9d), while in A. samurai sp. nov., F1 is shorter than pedicel (Figure 11d); radial cell of $A$. paretasmartinezi sp. nov. is 2.4 times as long as wide (Figure 9a), 2.8 times in A. samurai sp. nov. (Figure 11b); propodeal carinae of $A$. paretasmartinezi sp. nov. are well defined and thick, with slightly curved margins (Figure 9f), while in A. samurai sp. nov., propodeal carinae are narrow and well defined in the first twothirds and thick (Figure 11f).

- Type material: (1 9 ). Holotype $q$ (deposited in CNCI): C-410, Thailand: Doi Inthanon, Nat. Park, 70 km. SW. 1,250 m, Chiang Mai, 31.I-7.II.1989, T. V. Thormin lg, $+18^{\circ} 34^{\prime} 48.15^{\prime},+98^{\circ} 28^{\prime} 59.61^{\prime}$ : 1 오.

- Description: Length: female $1.4 \mathrm{~mm}$, male unknown. Coloration: head, yellow; mesosoma and metasoma, yellowish brown; antennae, yellow, darkening towards apical part; legs and veins, yellowish.
Antenna: female: F1 to F3 are smooth, thinner than remaining flagellomeres; F4 F11, with rhinaria and club-shaped. Antennal formula: 3.5 (1.8); 3.0 (1.5); 3.5 (1.0); 2.7 (1.0); 3.1 (1.2); 3.4 (1.4); F4 to F11 are subequal in length, width, and shape (Figure 9d). Mesosoma: pronotum has abundant setae, with fewer setae on posterodorsal margins, two thick carinae clearly visible (Figure 9c); apex of scutellum has few wrinkles; propodeum has many setae, two carinae are well defined, not joined at base, margins slightly curved (Figure 9f). Forewing has an open radial cell, 2.4 times as long as wide. $\mathrm{R} 1$ is short and slightly curved; Rs is long and curved (Figure 9a).

- Distribution. Oriental: Thailand.

- Etymology. This new species is dedicated to our friend Dr. Jordi Paretas-Martínez, for his contributions to the knowledge of the Charipinae, and 


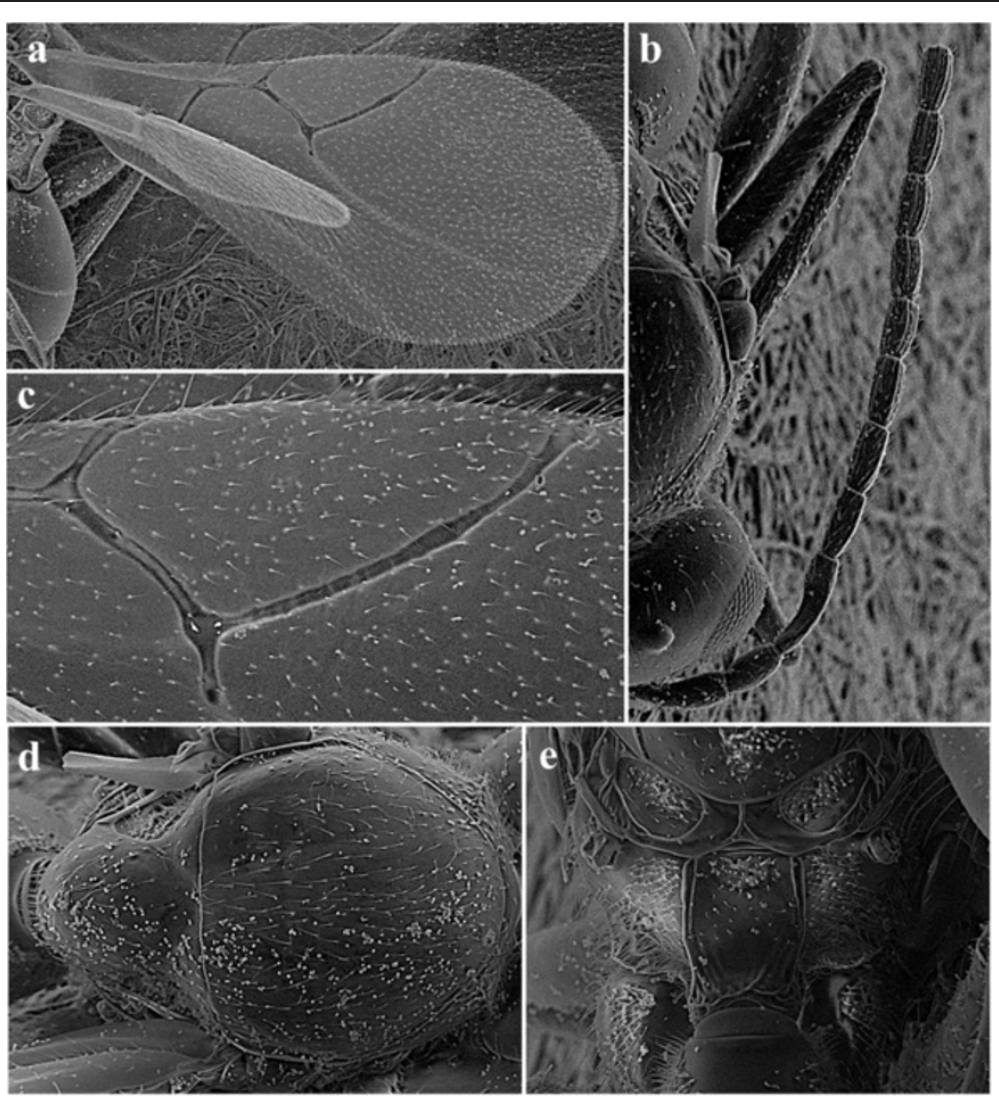

Figure 15 Phaenoglyphis indica Ferrer-Suay and Pujade-Villar sp. nov. (a) Forewing, (b) antenna, (c) radial cell, (d) mesoscutum, and (e) propodeum.

because he was the first person who recognized this species as new.

\section{Alloxysta pilosa Ferrer-Suay and Pujade-Villar sp. nov.}

The diagnosis, type material, description, distribution, and etymology are as follows:

- Diagnosis: A. pilosa sp. nov. is easily recognized having the body entirely covered by setae and a very large open radial cell (Figure 10a, b).

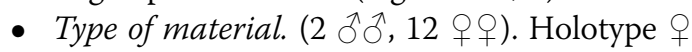
(deposited in CNCI): C-553, Taiwan: Nantou, Lienhanatge $750 \mathrm{~m}$, 20.II-18.IV.1991, C.H. Starr and C.S. Liu, $+23^{\circ} 52^{\prime} 28.33^{\prime},+120^{\circ} 58^{\prime} 16.13^{\prime}$. Paratypes $(1$ ऽ, 6 우): C-553, Taiwan: Nantou, Lienhanatge 750 m, 20.II-18.IV.1991, C.H. Starr and C.S. Liu: 3 우; C-465, Thailand: Chiang Mai, $70 \mathrm{~km}, \mathrm{SW}$, 3-12. V. 1990 M.T. Doi Inthanon Nat. Park, B.V. Brown, Oak for 1 ; C-182, Thailand: Doi Inthanon Nat. Park M. T., 6-12.VI.1990 B.V. Brown: 1 \%; C-543, Japan: Hokkaido, Hidaka Mts. below Pyo tan 500, 14.VIII.1996, L. Masner, S.S.J-12: 1 Oे; Nepal, Phulcoki, 2,600 m, 13.X.1988, Oak forest ss., A. Smetana, Alloxysta det. K. Schick, 1998: 1 J , 3 우;
Nepal, Ktmd. Godavari, 6000', 18.VII.1967, Mal. Tr., Can.Exp: 1 +; $28^{\circ} 00^{\prime}$ N. $85^{\circ} 00^{\prime}$ E. Mal.tr. 7, 9900', 2131 May 1967, Can. Nepal Exped.: 1 \%; 27 $7^{\circ} 6^{\prime} \mathrm{N} .85^{\circ}$ 00'E., Mal.tr.8, 10, 100', 17-23 May 1967, Can. Nepal Exped., Alloxysta det. K. Schick, 1999: 1 ㅇ. Paratypes: $1 \hat{O}$ and 7 우 0 deposited in $\mathrm{CNCI}$, and 1 $\widehat{\sigma}$ and 5 + 9 deposited in UB.

- Description. Length: female 0.9 to $1.1 \mathrm{~mm}$; male $1.2 \mathrm{~mm}$. Coloration: head, mesosoma, and metasoma, brown; scape, pedicel, and F1 to F3, yellow; F4 to F12, yellowish brown; legs, dark yellow; veins, yellowish brown. Antenna: female: F1 to F3 are smooth, thinner than remaining flagellomeres; F4 to F11, with rhinaria and club-shaped. Antennal formula: 3.2 (1.7); 2.5 (1.5); 3.0 (1.0); 3.0 (1.0); 3.2 (1.2); 3.2 (1.4); F4 to F11 are subequal in length, width, and shape (Figure 10d). Male: F1 and F2 are smooth, thinner than remaining flagellomeres; F3 to F12, with rhinaria and club-shaped. Antennal formula: 3.0 (1.4); 2.2 (1.3); 3.0 (0.8); 3.0 (0.7); 3.3 (0.9); 3.3 (1.0); F3 F12, subequal in length, width, and shape (Figure 10e). Mesosoma: pronotum has abundant setae, and two carinae are present (Figure 10g); propodeum has many setae, with no carinae present 

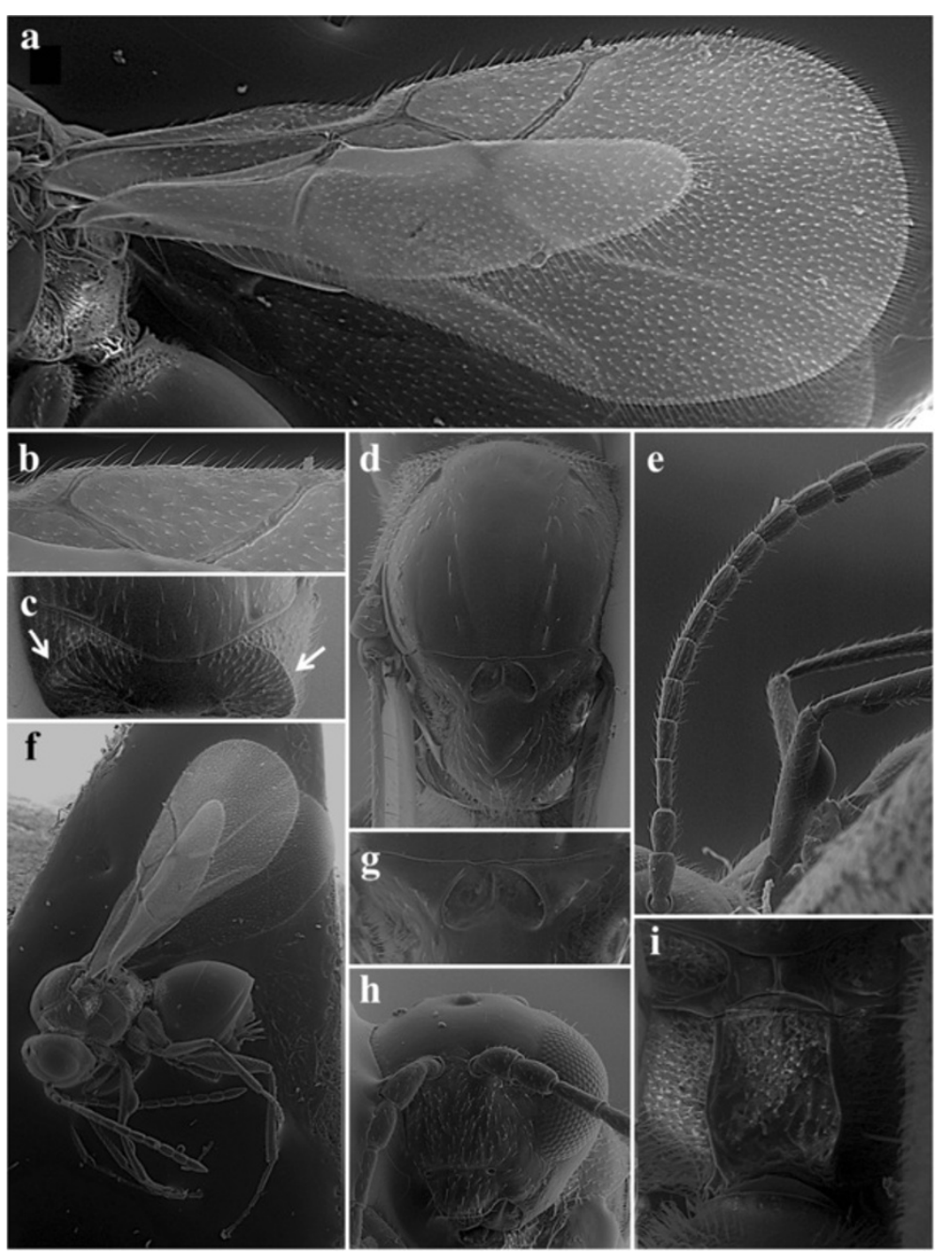

g
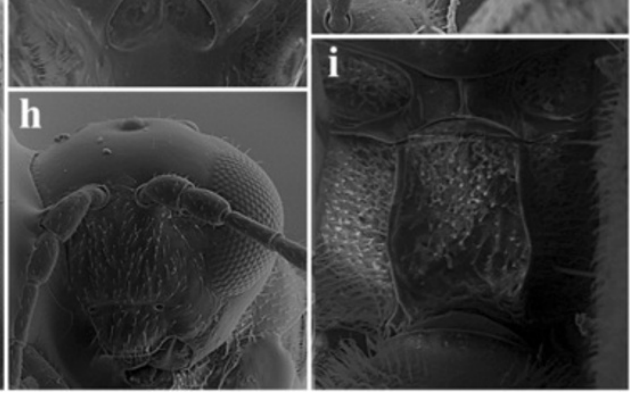

Figure 16 Phaenoglyphis japonica Ferrer-Suay and Pujade-Villar sp. nov. (a) Forewing, (b) radial cell, (c) pronotum, (d) mesoscutum, (e) antenna, (f) body, (g) detail of scutellar foveae, (h) head, and (i) propodeum.

(Figure 10f). Forewing has an open radial cell, 4.7 to 4.9 times as long as wide in females (Figure 10a), 3.2 times in males (Figure 10b). R1 is short and slightly curved; Rs is long and curved, not reaching the costal margin.

- Distribution. Eastern Palaearctic: Japan. Oriental: Nepal, Thailand, Taiwan.

- Etymology. The specific name refers to the abundant setae that cover the body of this species.

\section{Alloxysta pleuralis (Cameron, 1879)}

Allotria pleuralis Cameron, 1879: 113. Lectotype: BMNH.

The diagnosis, material examined, and distribution are as follows:

- Diagnosis. This species is easily differentiated from other Alloxysta species by the following combination of features: a partially open radial cell; pronotal carinae is present; two well-defined propodeal carinae reaching the base independently; in female antennae, F1 is longer than F2, F2 is shorter than F3, and F3 is shorter than F4; in male antennae, F1 to F3 are subequal in length and slightly curved.

- Material examined. (1 +). Alloxysta sp., IndiaRajori, Bodhan, 08-IV-2008, Swept - Z. Ahmed. (Deposited in CNCI).

- Distribution. Species was previously known to be from Palaearctic. This species was previously mentioned to be from Asia, in India by Ahmad and Singh (1996) and in Israel by Argaman (1988).

\section{Alloxysta pusilla (Kieffer, 1902)}

Allotria (Allotria) pusilla Kieffer, 1902: 13. Type: NHMA (Dessart 1969: 192). 
The diagnosis, material examined, and distribution are as follows:

- Diagnosis. A. pusilla is similar to A. tscheki in both having a closed radial cell, pronotal carinae, and F1 longer than pedicel in female. They can be distinguished by A. pusilla having a radial cell 2.1 times as long and as wide, while 1.8 times in $A$. tscheki; and F1 to F3 of males of $A$. pusilla is slightly curved, while in males of $A$. tscheki, only F3 is slightly curved. A. pusilla and $A$. tscheki are close to $A$. nepalica sp. nov., but $A$. nepalica sp. nov. has very long antennae and a very large radial cell.

- Material examined. (1 ô, 18 o o ). C-465, Thailand: Chiang Mai, 70Km, SW, 3-12. V. 1990 M.T. Doi Inthanon Nat. Park, B.V. Brown, Oak for: 2 q; C-172, Taiwan: Wasche, 1,150 m, 3.V.1983, H. Townes Fit: 1 ; C C-402, Taiwan: Nanton Mei Jang, 2,100 m (well forest), 19.IX-16.XII.1990, C.S. Lin: 1 ; C-553, Taiwan: Nantou, Lienhanatge 750 m, 20. II-18.IV.1991, C.H. Starr and C.S. Liu: 5 q $q$; C476, Taiwan: Taitung Hsien, Hsinkangshan above, Shang Kang, 800 m, 17-22.IV.1998, A. Smetana and Lise Robilland:

2 우; C-312, Japan: Ibaraki, Tsukuba, NIAES, 1525.VII.1989, M.J. Sharkey, Pt: 1 đ; C-477, Taiwan: Shan-Lin-Lhi (Nanton Hsien) 1,600 m, 16.V.1950, Fit and Pans, Primory for J. La Salle: 7 우오. All materials were deposited in $\mathrm{CNCI}$, except 4 우 which were deposited in UB.

- Distribution. It is previously known to be from Palaearctic. This species was previously mentioned to be from Asia, in Iran by Ferrer-Suay et al. (2013). New records are from Japan and the Oriental region (Thailand, Taiwan).

Alloxysta samurai Ferrer-Suay and Pujade-Villar sp. nov. The diagnosis, type material, description, distribution, and etymology are as follows:

- Diagnosis: A. samurai sp. nov. is similar to $A$. paretasmartinezi sp. nov., but in $A$. samurai sp. nov., rhinaria begin in F4 (Figure 11d), while in $A$. paretasmartinezi sp. nov., rhinaria begin in F3 (Figure 9e); F1 of $A$. samurai sp. nov. is shorter than the pedicel (Figure 11d), while in $A$.

paretasmartinezi sp. nov., F1 is slightly longer than the pedicel (Figure 9d); radial cell of A. samurai sp. nov. is 2.8 times as long and as wide (Figure 11b), while it is 2.4 times in $A$. paretasmartinezi sp. nov. (Figure 9a).

- Type material. (1 9 ). Holotype $q$ (deposited in CNCI): C-546, Japan: Hokkaido, Sapporo, Jozankei, 27-28.IX.1989, 350 m, K., +42 $57^{\prime} 8.65^{\prime},+141^{\circ} 9^{\prime} 3.49^{\prime}$.
- Description. Length: female $1.2 \mathrm{~mm}$; male unknown. Coloration: head, mesosoma, and metasoma, yellowish brown; scape, pedicel, and flagellomeres, yellow and darkening towards apical part; legs and veins, yellowish. Antenna: female: F1 to F3 are smooth, thinner than remaining flagellomeres; F4 F11, with rhinaria and club-shaped. Antennal formula: 2.8 (1.6); 3.0 (1.2); 2.7 (0.8); 1.8 (0.8); 2.0 (0.9); 3.2 (1.2); F4 to F11 are subequal in length, width, and shape (Figure 11d). Mesosoma: pronotum has few setae, with two clearly visible thick, long carinae (Figure 11c); apex of scutellum has several thick, straight carinae; propodeum has abundant setae, two well-defined carinae, thinner on top and wider at the bottom, not joining at the base of the propodeum (Figure 11f). Forewing has an open radial cell, 2.8 times as long as wide. R1 is short and slightly curved; Rs is long and curved (Figure 11a, b).

- Distribution. Eastern Palaearctic: Japan.

- Etymology. Specific name refers to warriors from old Japan, the country where the specimen was collected.

\section{Alloxysta sawoniewiczi (Kierych, 1988)}

Adelixysta sawoniewiczi Kierych, 1988: 351. Type: MZPW (Kierych 1988: 353).

The diagnosis, material examined, short description, and distribution are as follows:

- Diagnosis. A. sawoniewiczi is similar to $A$. arcuata both having a closed radial cell, pronotal and propodeal carinae, and F1 subequal to pedicel. They can be distinguished by $A$. sawoniewiczi having antennae shorter than the body length, while in $A$. arcuata, they are longer; in A. sawoniewiczi, rhinaria begin in F5 in females (Figure $2 \mathrm{~g}$ ) and F4 in males, while in A. arcuata, rhinaria begin in F3 in females (Figure 2a) and F2 in males; in A. sawoniewiczi, there are narrow and well-defined propodeal carinae at the upper half and wide and forming a plate at the lower half with sharp margins, while in $A$. arcuata, propodeal carinae are forming a complete plate with few setae on top and margins are slightly curved.

- Material examined. (18 우). C-465, Thailand: Chiang Mai, 70 km, SW, 3-12. V. 1990 M.T. Doi Inthanon Nat. Park, B.V. Brown, Oak for 1 q; C172, Taiwan: Wasche, 1,150 m, 3.V.1983, H. Townes

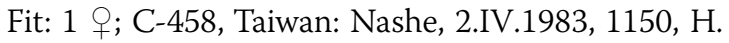
Towres, Fit.: 2 우; C-477, Taiwan: Shan-Lin-Lhi (Nanton Hsien) 1,600 m, 16.V.1950, Fit and Pans, Primory for J. La Salle: 9 우; Nepal, Ktmd. 
Godavari, 6000', 3 Aug. 1967, Can.Nepal Exped.: 1 + ; Nepal, Ktmd. Godavari, $6000^{\prime}, 18$. VII. 1967, Can. Nepal Exped.: 1 \%; $28^{\circ} 00^{\prime} \mathrm{N}, 85^{\circ} 00^{\prime} \mathrm{E}$, Mal.tr. 7, 9900', 30 May. 1967, Can.Nepal Exped.: 1 ; $28^{\circ} 00^{\prime}$ N, 850'ㄹ, Mal.tr. 6, 10, 500', 9-12 May. 1967, Can.Nepal Exped.: 1 \%; "Nepal, Ktmd. Pulchauki, 7300' 14-21. VII. 1967, Mal. Tr., Can. Exp.: 1 q. All materials are deposited in $\mathrm{CNCI}$ except 8 우 which are deposited in UB.

- Short description. Head, mesosoma, and metasoma, brown; antennae, yellowish and slightly darkening towards apical part; legs, dark yellow; veins, yellowish brown. In females, F1 to F4 are smooth, thinner than remaining flagellomeres; F5 F11, with rhinaria and club-shaped; F1 is subequal to the pedicel and longer than F2, F2 is shorter than F3, and F3 is shorter than F4 (Figure 2g). In male antennae, F1 F3 are smooth, thinner than remaining flagellomeres; F4 to F12, with rhinaria and club-shaped; F1 is shorter than the pedicel. Pronotum has sparse setae, more abundant on the anterior margin, with two clearly visible carinae. Propodeum has many setae, with two narrow and well-defined carinae at the upper half, wide and forming a plate at the lower half, with sharp edges. Forewing is longer than the body; radial cell is closed, 2.3 times as long as wide (Figure 5f).

- Distribution. It is previously known to be from the Palaearctic region. New record is from the Oriental region (Nepal, Thailand, Taiwan).

\section{Alloxysta sharkeyi Ferrer-Suay and Pujade-Villar sp. nov.}

The diagnosis, type material, description, distribution, and etymology are as follows:

- Diagnosis. This species is easily differentiated from other Alloxysta species by the partially open radial cell lacking propodeal carinae (Figure 12f) and rhinaria begin in F1 (Figure 12e).

- Type material. (3 $\circ$ ㅇ). Holotype $q$ (deposited in CNCI): C-444, Japan: Kumamoto, M.T. Kurotake, 900 m, 14.V.1989, M. Sharkey sweep, $+32^{\circ} 49^{\prime} 43.78^{\prime}$, $+130^{\circ} 42^{\prime} 30.48^{\prime}$. Paratypes (2 우): C-444, Japan: Kumamoto, M.T. Kurotake, 900 m, 14.V.1989, M. Sharkey sweep: 1 우 C-546, Japan: Hokkaido, Sapporo, Jozankei, 27-28.IX.1989, 350 m, K. Maetox, M. Sharkey M.T.: 1 . Paratypes: 1 deposited in $\mathrm{CNCI}$, and 19 deposited in UB.

- Description. Length: female $1.4 \mathrm{~mm}$; male unknown. Coloration: head, mesosoma, and metasoma, dark brown; antennae, yellow and slightly darkening towards apical part; legs, dark yellow; veins, yellowish brown. Antenna: female: F1 to F11, with rhinaria and club-shaped. Antennal formula: 3.0
(1.6); 2.3 (1.5); 3.7 (1.0); 2.7 (1.0); F2 to F11 are subequal in length, width, and shape (Figure 12e).

Mesosoma: pronotum has many setae, less abundant on posterodorsal margins, with two long carinae present (Figure 12c); propodeum is entirely covered with abundant setae, with no carinae present (Figure 12f). Forewing has a partially open radial cell, 2.9 times as long as wide. R1 is short and slightly curved; Rs is long and curved (Figure 12a, b).

- Distribution. Eastern Palaearctic: Japan.

- Etymology. This species is dedicated to the collector, M. Sharkey.

\section{Alloxysta tscheki (Giraud, 1860)}

Allotria tscheki Giraud, 1860: 128. Type: unknown.

The diagnosis, material examined, and distribution are as follows:

- Diagnosis. A. tscheki is similar to A. pusilla in both having a closed radial cell, pronotal carinae, and F1 is longer than pedicel in females. They can be distinguished by $A$. tscheki having a radial cell 1.8 times as long as wide (Figure $5 \mathrm{~g}$ ), while 2.1 times in A. pusilla (Figure 5e); in males of $A$. tscheki, only F3 is slightly curved, while in males of $A$. pusilla, F1 to F3 are slightly curved. A. tscheki and A. pusilla are close to A. nepalica sp. nov., but $A$. nepalica sp. nov. has very long antennae and a very large radial cell (Figure 7).

- Material examined. (1 đo). C-444, Japan: Kumamoto, M.T. Kurotake, 900 m, 14.V.1989, M. Sharkey

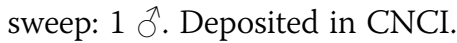

- Distribution. It is previously known to be from the Palaearctic region. This species was previously mentioned to be from Asia, in Iran by Ferrer-Suay et al. (2013). New record is from Japan.

\section{Alloxysta victrix (Westwood, 1833)}

Allotria victrix Westwood, 1833: 495. Type: OUMNH (Andrews 1978: 92).

The diagnosis, material examined, short description, and distribution are as follows:

- Diagnosis. A. victrix is easily differentiated from all other Alloxysta species present because it is the only species with a closed radial cell that does not have propodeal carinae.

- Material examined. (1 \&). C-385, Japan: Ibaraki, Tsukuba, NIAES, 31.V-8.VI.1989, M.T., M.J. Sharkey: 1 ; deposited in CNCI.

- Short description. Head, dark yellow; mesosoma and metasoma, dark brown; scape, pedicel, F1, and F2, 
yellow; F3 to F11, yellowish brown; legs, yellow; veins, brown. In females, F1 and F2 are smooth, thinner than remaining flagellomeres; F3 to F12, with rhinaria and club-shaped; F1 is longer than the pedicel and F2; F2 to F4 are subequal (Figure 2i). In males, they are similar to females, but F1 to F3 are curved (F1 is slightly curved, while F2 and F3 are clearly curved). Pronotum has sparse setae; two carinae are clearly visible. Propodeum has abundant pubescence; no carinae are present and lacking setae on longitudinal areas where carinae are present in other species. Forewing is longer than the body; radial cell is closed, 3.0 times as long as and wide (Figure $5 \mathrm{~h}$ ).

- Distribution. Cosmopolitan. New record is from Japan.

\section{Alloxysta xanthopa (Thomson, 1862)}

Allotria xanthopa Thomson, 1862: 408. Lectotype: MZLU.

The diagnosis, material examined, short description, and distribution are as follows:

- Diagnosis. A. xanthopa resembles A. paretasmartinezi sp. nov. because both species have an open radial cell, pronotal carinae present, beginning of rhinaria in F3, and propodeal carinae present. However, they can be differentiated by shape of propodeal carinae: forming a plate with sides slightly curved in A. xanthopa, while well defined and thick reaching the base independently, with sides slightly curved in A. paretasmartinezi sp. nov.; absence of carinae on apex of scutellum in $A$. xanthopa, while with few wrinkles in $A$. paretasmartinezi sp. nov.

- Material examined. (1 +). $27^{\circ} 57^{\prime}$ N. $84^{\circ} 59^{\prime} \mathrm{E}$, Mal. tr.5, 10, 100', 19-26 May 1967, Can.Nepal.Exped.; deposited in CNCI.

- Short description. Head, yellowish brown; mesosoma and metasoma, dark brown; antennae, yellow; legs and veins, yellow. In females, F1 and F2 are smooth, thinner than remaining flagellomeres; F3 F11, with rhinaria and club-shaped; F1 is longer than the pedicel and F2, F2 is shorter than F3, and F3 and F4 are subequal in length (Figure $2 \mathrm{~m}$ ); male, unknown. Pronotum is covered with many setae with two clearly visible thick carinae. Propodeum is covered by a lot of setae, with two propodeal carinae forming a wide plate with slightly curved sides. Forewing is longer than the body; radial cell is open, 2.6 times as long as wide (Figure 5l).

- Distribution. Species was previously known to be from Palaearctic region. New record is from the Oriental region (Nepal).

\section{Genus Phaenoglyphis Förster, 1869}

Phaenoglyphis Förster, 1869: 338. Type species: Phaenoglyphis xanthochroa Förster, 1869.

A detailed description of the common characters for all Phaenoglyphis species is given below. The known Phaenoglyphis species present in Asia are briefly described, and for the new ones, only important characters, basically from the antenna and mesosoma, useful for distinguishing among them, are presented:

- Head. It is transversally ovate, smooth, shiny, and slightly wider than high in frontal view. Setae are below and between toruli, without setae above toruli. Few scattered setae are on the vertex; many setae are on the face. Transfacial line is 1.1 to 1.2 times the height of the compound eye. Malar space is 0.3 to 0.4 times the height of the compound eye.

- Antenna. Female: 13-segmented, filiform; all antennomeres are with sparse setae. Male: 14-segmented, filiform; all antennomeres are with sparse setae.

- Mesosoma. Pronotum is entirely covered by long setae, with two clearly visible thick, long carinae. Mesoscutum is smooth, shiny, and round in dorsal view, with scattered setae. Scutellum is smooth and shiny with scattered setae and is more abundant on the apex. Propodeum is covered by setae, with two thin well-separated carinae.

- Forewing. It is longer than the body and 1.3 to 1.6 times as long as the mesosoma and metasoma together. It is covered with dense pubescence; marginal setae are present.

- Metasoma. Anterior part has incomplete ring of setae, is glabrous at the center, and wider laterally. Metasoma is smooth and shiny; T3 and T4 are clearly distinguishable.

\section{Phaenoglyphis asiatica Ferrer-Suay and Pujade-Villar sp. nov.}

The diagnosis, type material, description, distribution, and etymology are as follows:

- Diagnosis. P. asiatica sp. nov. is similar to P. villosa and $P$. chinensis sp. nov. because these three species are the only Phaenoglyphis species with a partially open radial cell. $P$. asiatica sp. nov. differs from $P$. villosa by scutellar foveae which are absent in P. asiatica sp. nov. (Figure 13d) but present in P. villosa, and they also differ in the grade of pilosity, as in P. asiatica sp. nov., the pronotum and mesoscutum are covered by abundant setae (Figure 13d, e), while in P. villosa, there are scattered setae on the pronotum and mesoscutum. $P$. asiatica sp. nov. differs from $P$. chinensis sp. nov. in the beginning of rhinaria and club-shaped, 
which are in F2 in P. asiatica sp. nov. (Figure 13b) but in F3 in P. chinensis sp. nov. (Figure 14c); the size of radial cell is at 2.6 in $P$. asiatica sp. nov. (Figure 13a) and 3.8 in P. chinensis sp. nov. (Figure 14a).

- Type material. (1 q). Holotype $q$ (deposited in CNCI): (C-444) Japan, Kumamoto, Mt. Kuratake, 900 m, 14.V.1989, sweep M. Sharkoy, $+32^{\circ} 49^{\prime}$ $43.78^{\prime},+130^{\circ} 42^{\prime} 30.48^{\prime}$.

- Description. Length: female $1.1 \mathrm{~mm}$; male unknown. Coloration: head, mesosoma, and metasoma, brown; antenna, yellow and darkening towards end; legs, dark yellow; veins, yellowish brown. Antenna: female: F1 is thinner than the remaining flagellomeres; F2 to F11, with rhinaria and clubshaped. Antennal formula: 3.2 (1.7); 4.3 (1.0); 3.2 (1.4); 3.0 (1.6); 2.9 (1.6) (Figure 13b). Mesosoma: notauli are not present; without scutellar foveae (Figure 13d). Forewing has a partially open radial cell, 2.6 times as long and as wide. R1 is short and straight; Rs is long slightly curved (Figure 13a).

- Distribution. Eastern Palaearctic: Japan.

- Etymology. The specific name refers to the continent where it was collected.

\section{Phaenoglyphis chinensis Ferrer-Suay and Pujade-Villar} sp. nov.

The diagnosis, type material, description, distribution, and etymology are as follows:

- Diagnosis. P. chinensis sp. nov. is similar to $P$. villosa and $P$. asiatica sp. nov. because these three species are the only Phaenoglyphis species with a partially open radial cell. P. chinensis sp. nov. differs from $P$. villosa by the scutellar foveae which are absent in $P$. chinensis sp. nov. (Figure 14b) but present in $P$. villosa, and they also differ in the grade of pilosity, as in $P$. chinensis sp. nov., the pronotum and mesoscutum are covered by abundant setae (Figure 14b, e), while P. villosa has scattered setae on the pronotum and mesoscutum; size of radial cell is 3.8 in $P$. chinensis sp. nov. (Figure 14a), while it is 2.1 to 2.7 in P. villosa. Phaenoglyphis chinensis sp. nov. differs from $P$. asiatica sp. nov. in the beginning of rhinaria and club-shaped: in F3 in P. chinensis sp., nov.

(Figure 14c) but in F2 in P. asiatica sp. nov. (Figure 13b); radial cell is 3.8 in P. chinensis sp. nov. (Figure 14a), while it is 2.6 in P. asiatica sp. nov. (Figure 13a).

- Type material. (1 $ᄋ$ ). Holotype 9 (deposited in CNCI): (C-408) China, N. Yunnan, Xuo Shan, $10 \mathrm{~km}$ W., Zhongdien, $400 \mathrm{~m}, 24-26 . V I .1996$, A. Smetana, $+23^{\circ} 58^{\prime} 45.38^{\prime}$, +97 $53^{\prime} 41.87^{\prime}$.
- Description. Length: female $1.0 \mathrm{~mm}$; male unknown. Coloration: head, mesosoma, and metasoma, brown; scape, yellowish brown; pedicel and F1 to F11, yellowish brown; legs, dark yellow; veins, yellowish brown. Antenna: female: F1 and F2 are thinner than the remaining flagellomeres; F2 to F11, with rhinaria and club-shaped. Antennal formula: 2.0 (1.3); 2.5 (0.7); 2.5 (0.7); 2.7 (1.0); 2.7 (1.0) (Figure 14c). Mesosoma: notauli are not present; without scutellar foveae (Figure 14b). Forewing has a partially open radial cell, 3.8 times as long as wide. R1 is short and slightly curved; Rs is long and also slightly curved (Figure 14a).

- Distribution. Oriental region: China.

- Etymology. The specific name refers to the country where it was collected.

\section{Phaenoglyphis indica Ferrer-Suay and Pujade-Villar sp. nov.}

The diagnosis, type material, description, distribution, and etymology are as follows:

- Diagnosis. P. indica sp. nov. is easily differentiated from other Phaenoglyphis species present in Asia because it is the only species with a completely open radial cell.

- Type material. $(1 \lesssim$ ). Holotype $\widehat{\delta}$ (deposited in BMNH): India, Kashmir, Srinagar, R.E. Bhagat, on Neseta, a.c. Bhagat, No. 12, C.I.E.A. 10413, $34^{\circ} 2^{\prime}$ 38.3382', 744ㅇ' $7.9806^{\prime}: 1$ ठ․

- Description. Length: female unknown; male $1.1 \mathrm{~mm}$. Coloration: head, mesosoma, and metasoma, brown; antennae, yellow and darkening towards end; legs, dark yellow; veins yellowish brown. Antenna: male: F1 is smooth and thinner than the remaining flagellomeres; F2 to F12, with rhinaria and clubshaped; F1 is clearly curved. Antennal formula: 3.0 (1.5); 5.0 (1.0); 3.3 (1.4); 3.3 (1.5); 3.3 (1.5)

(Figure 15b). Mesosoma: notauli are present; scutellar foveae are not present (Figure 15d). Forewing has a completely open radial cell, 2.3 times as long as wide. R1 is short and straight; Rs is long and slightly curved (Figure 15a, c).

- Distribution. Oriental region: India.

- Etymology. The specific name refers to the country where it was collected.

\section{Phaenoglyphis japonica Ferrer-Suay and Pujade-Villar sp. nov.}

The diagnosis, type material, description, distribution, and etymology are as follows:

- Diagnosis. P. japonica sp. nov. is easily differentiated from other Phaenoglyphis species present in Asia. It 
Table 1 Species treated in this study with their previously known and newly recorded distribution areas

\begin{tabular}{|c|c|c|}
\hline Species & Previously known & Newly recorded \\
\hline A. arcuata & Palaearctic and Neotropical & Oriental (Thailand, Taiwan) \\
\hline A. brevis & Palaearctic and Neotropical & (India, Thailand) \\
\hline \multirow[t]{2}{*}{ A. castanea } & Palaearctic and Neotropical & Eastern Palaearctic (Japan, Nepal, South Korea) \\
\hline & & Oriental (Malaysia, Taiwan) \\
\hline A. consobrina & Cosmopolitan & Oriental (India) \\
\hline \multirow[t]{2}{*}{ A. melanogaster } & Palaearctic & Eastern Palaearctic (Japan) \\
\hline & & Oriental (Thailand, Taiwan) \\
\hline A. obscurata & Holarctic & Eastern Palaearctic (Japan) \\
\hline A. pallidicornis & Holarctic & Eastern Palaearctic (Nepal \\
\hline A. pleuralis & Palaearctic & \\
\hline \multirow[t]{2}{*}{ A. pusilla } & Palaearctic & Eastern Palaearctic (Japan) \\
\hline & & Oriental (Thailand, Taiwan) \\
\hline A. sawoniewiczi & Palaearctic & Oriental (Nepal, Thailand, Taiwan) \\
\hline A. tscheki & Palaearctic & Eastern Palaearctic (Japan) \\
\hline A. victrix & Cosmopolitan & Eastern Palaearctic (Japan) \\
\hline A. xanthopa & Palaearctic & Oriental (Nepal) \\
\hline P. longicornis & Palaearctic & Oriental (India) \\
\hline P. stricta & Palaearctic & Eastern Palaearctic (Japan) \\
\hline P. villosa & Cosmopolitan & Oriental (India) \\
\hline P. xanthochroa & Palaearctic & Eastern Palaearctic (Japan) \\
\hline
\end{tabular}

differs from $P$. insperatus in the relation between the antennae and body length, with the antennae shorter or subequal to the body length in $P$. japonica sp. nov., while longer in P. insperata; beginning of rhinaria and club shape is in F3 in $P$. japonica sp. nov. and in F1 in P. insperata; scutellar foveae of $P$. japonica sp. nov. are with indistinctly defined anterior and posterior margins, while in $P$. insperata, only the posterior margin not clearly defined. It differs from $P$. longicornis and P. stricta in the beginning of rhinaria and club shape: in F3 in $P$. japonica sp. nov., while in F1 in P. longicornis.

- Type material. (1 9 ). Holotype 9 (deposited in CNCI): C-549, Japan: Hokkaido, Horoka 800 m, 5. VIII.1989, Sweep H.J. Sharkey, $+42^{\circ} 54^{\prime} 46.58^{\prime},+141^{\circ}$ $47^{\prime} 59.46^{\prime}$.

- Description. Length: female $1.4 \mathrm{~mm}$; male unknown. Coloration: head, mesosoma, and metasoma, yellowish brown; scape, yellowish brown; pedicel, F1, and F2, dark yellow; F3 to F11, yellowish brown; legs, dark yellow; veins, yellowish brown. Antenna: female: F1 and F2 are smooth, thinner than remaining flagellomeres; F3 to F11, with rhinaria and club-shaped. Antennal formula: 3.2 (1.8); 3.0 (1.8); 3.3 (1.0); 2.7 (1.4); 2.8 (1.5) (Figure 16e). Mesosoma: notauli are present. Oval scutellar foveae are separated by a carina; anterior and posterior margins are not clearly defined (Figure $16 \mathrm{~g}$ ). Forewing has a closed radial cell, 2.4 times as long as wide. R1 is short and straight; Rs is long and slightly curved (Figure 16b).

- Distribution. Eastern Palaearctic: Japan.

- Etymology. The specific name refers to the country where it was collected.

\section{Phaenoglyphis longicornis (Hartig, 1840)}

Xystus longicornis Hartig, 1840: 199. Holotype: ZSM.

The diagnosis, material examined, short description, and distribution are as follows:

- Diagnosis. P. longicornis differs from P. japonica sp. nov. in the beginning of rhinaria and club shape: in F1 in $P$. longicornis, while in F3 in P. japonica sp. nov. It differs from $P$. insperata and $P$. stricta in the proportion between flagellomeres: F2 is subequal to F3, and F3 is shorter than F4 in P. longicornis, but F2 F4 are subequal in length in $P$. insperata and $P$. stricta.

- Material examined. (1 ). Alloxysta sp., IndiaRajori, Bodhan, 08-IV-2008, swept - Z. Ahmed: 1 q; deposited in UB.

- Short description. Head, mesosoma, and metasoma, dark brown; scape, yellowish brown; pedicel and rest of flagellomeres, dark yellow; legs, yellow; veins, yellowish brown. Female antennae, 13-segmented; 
F1 to F11, with rhinaria and club-shaped; F1 longer than pedicel and F2, F2 subequal to F3, and F3 shorter than F4; male unknown. Pronotum has abundant setae and two clearly visible long, thick carinae; notauli are present. Oval scutellar foveae with straight margins, separated by carina, and not delimited at the bottom. Propodeum has abundant pubescence, with two thin carinae joining at the base. Forewing is longer than the body; radial cell is closed, 2.7 times as long as wide.

- Distribution. It is previously known to be from the Palaearctic region. New record is from the Oriental region (India).

\section{Phaenoglyphis stricta (Thomson, 1877)}

Allotria (Auloxysta) stricta Thomson, 1877: 812. Lectotype: MZLU.

The diagnosis, material examined, short description, and distribution are as follows:

- Diagnosis. P. stricta differs from P. japonica sp. nov. in the beginning of rhinaria and club shape: in F1 in $P$. stricta, while in F3 in P. japonica sp. nov. It differs from $P$. longicornis in the proportion between flagellomeres: F2 is subequal to F3, and F3 is shorter than F4 in P. longicornis, but F2 to F4 are subequal in length in $P$. stricta. It differs from $P$. insperatus in the shape of scutellar foveae: with straight sides and not delimited at the top or bottom in P. stricta, while rounded and not delimited at the bottom in P. insperatus.

- Material examined. (1 9$)$. (C-444) Japan, Kumamoto, Mt. Kuratake, 900 m, 14.V.1989, sweep M. Sharkoy; deposited in CNCI.

- Short description. Head, mesosoma, and metasoma, dark brown; scape, yellowish brown; pedicel, F1, and F2, dark yellow; rest of flagellomeres, yellowish brown; legs, yellow; veins, yellowish brown. In female antennae, F1 to F11, with rhinaria and clubshaped; F1 longer than pedicel and F2; F2 to F4, subequal in length. Pronotum has abundant setae and two clearly visible long, thick carinae; notauli are present. Oval scutellar foveae are present, separated by carina and not delimited at the top or bottom. Propodeum has abundant pubescence, with two straight, thin carinae reaching the base independently. Forewing is longer than the body; radial cell is closed, 2.7 times as long as wide; male unknown.

- Distribution. It is previously known to be from the Palaearctic region. New record is from Japan.

Phaenoglyphis villosa (Hartig, 1841)

Xystus villosus Hartig, 1841: 353. Holotype: ZSM.
The diagnosis, material examined, and distribution are as follows:

- Diagnosis. P. villosa is similar to P. asiatica sp. nov. and $P$. chinensis sp. nov. because these three species are the only Phaenoglyphis species with a partially open radial cell. $P$. villosa differs from $P$. asiatica sp. nov. and $P$. chinensis sp. nov. by the presence of scutellar foveae, being absent in $P$. asiatica sp. nov. (Figure 13d) and P. chinensis sp. nov. (Figure 14b) but present in $P$. villosa; they also differ in the grade of pilosity, with pronotum and mesoscutum of $P$. asiatica sp. nov. and P. chinensis sp. nov. covered with abundant setae (Figures 13e, d and 14b, e), while $P$. villosa has scattered setae on pronotum and mesoscutum; size of radial cell is at 2.1 to 2.7 in $P$. villosa but 3.8 in P. chinensis sp. nov. (Figure 14A).

- Material examined. (1 đ). Binodoxys indicus, Aphis craccivora, Vicia fabae, India, 02-I-2007; deposited in CNCI.

- Distribution. Cosmopolitan. This species was previously mentioned to be from Asia, in Iraq by Al-Jassani and Al-Adil (1986), in Iran by PujadeVillar et al. (2010), in Japan by Pujade-Villar et al. (2007) and Takada and Nakamura (2010), and in China and Taiwan by Pujade-Villar et al. (2007). New record is from India.

\section{Phaenoglyphis xanthochroa (Förster, 1869)}

Phaenoglyphis xanthochroa Förster, 1869: 339. Lectotype: ZMHB.

The diagnosis, material examined, short description, and distribution are as follows:

- Diagnosis. P. xanthochroa is easily differentiated from the other Phaenoglyphis species present in Asia because of its dark yellow body and deeply excavated notaulices.

- Material examined. (1 今̂). (C-400) Japan, Hokkaido, Tomuraushi area, 13.VIII.96, 500 m, L. Masner; deposited in CNCI.

- Short description. Head, mesosoma, and metasoma are dark yellow; scape, pedicel, F1, and F2, dark yellow, F3 to F12, yellowish brown; legs, yellow; veins, yellowish brown. In females, F1 and F2 are smooth and thinner than the remaining flagellomeres, F3 to F11 are with rhinaria and clubshaped; F1 is longer than pedicel and F2, F2 is shorter than F3, and F3 is subequal to F4. In males, $\mathrm{F} 1$ and F2 are smooth and thinner than the remaining flagellomeres, F3 to F11 are with rhinaria and club-shaped; F1 is curved; F1 is longer than the pedicel and F2, F2 to F4 are subequal in length. Pronotum has abundant setae and two clearly visible 
long, thick carinae. Notauli are present and deeply excavated. Oval scutellar foveae are present, separated by carina and completely defined. Propodeum has abundant pubescence, with two carinae slightly curved in the last one third, reaching the base independently. Forewing is longer than body; radial cell is closed, 2.5 times as long as wide.

- Distribution. It is previously known to be from the Palaearctic region. New record is from Japan.

\section{Conclusions}

The study of the Charipinae from Asia has been very limited. In total, 28 different species were previously cited in this area. In this paper, 19 additional species were identified (11 of which are new species): $A$. asiatica sp. nov., A. nepalica sp. nov., A. nippona sp. nov., A. obscurata, A. pallidicornis, A. paretasmartinezi sp. nov., A. pilosa, A. samurai sp. nov., A. sawoniewiczi, A. sharkeyi sp. nov., A. victrix, $A$. xanthopa, $P$. asiatica sp. nov., $P$. chinensis sp. nov., $P$. indica sp. nov., $P$. japonica sp. nov., $P$. longicornis, $P$. stricta, and $P$. xanthochroa. For Alloxysta, this study significantly increased the number of species known in this biogeographical region to a total of 27 . New records were also established for previously known species (Table 1).

The majority of Charipinae species were described from the Western Palaearctic and Nearctic regions. Biodiversity of this subfamily is very poorly known in most biogeographical regions: Australian, Oriental, Eastern Palaearctic, Afrotropical, and Neotropical. Detailed studies of the Charipinae from these regions are needed to clarify and improve the knowledge about their biology, diversity, and biogeography.

The type material of $P$. bangalorensis was not found. After studying its original description, some characters indicate that this species should not belong to the Charipinae: body length 3.5 to $3.75 \mathrm{~mm}$ (charipines usually reach 1.5 to $1.8 \mathrm{~mm}$ at most), antennae ending with a complete club, anterior margin of pronotum with angular corners, lateral to parapsidal furrows two deep and broad foveae one on either side with many broad pits in it, and propodeum with very rough reticulate carinate sculpturing. Nevertheless, until the type of material can be studied, we consider $P$. bangalorensis as incertae sedis. The holotype of $A$. simplex is incomplete as the metasoma and propodeum are lost. The presence or absence of propodeal carinae is an important diagnostic feature in the Alloxysta genus, so this species cannot be identified and is also considered here to be nomen dubium. The holotype of A. ishizawai was also revised, and it was found that its main diagnostic features correspond to P. ruficornis: apart from the radial cell and proportions between flagellomeres, the two species coincide in the abundant pubescence on the mesoscutum, the presence of notauli, having few wrinkles on the distal side of the notauli, and the presence of horizontally elongated scutellar foveae, separated by a carina and not delimited at the bottom. For these reasons, a new synonymy is hereby established. Alloxysta chinensis have been recently described by Fülop et al. (2013) from China, but unfortunately, it corresponds to A. sawoniewiczi, and for this reason, we establish here this new synonymy. After studying the type material of $A$. capillata and $A$. ruficollis, it was concluded that they are the same species as A. castanea (Ferrer-Suay et al., in preparation). For these reasons, these species were not included in the following key.

In Asia, 1 species of Lobopterocharips, 5 Dilyta, 10 Phaenoglyphis, and 27 Alloxysta are present. A key to the identity of all Charipinae species present in this area is given:

1. Forewing with undulation present in apical part of posterior margin (Figure 1a). Antenna with a cup-shaped pedicel

Pujade-Villar, 2007)

- Only 1 species of this genus is known, and up to now has only been recorded in Nepal

L. arreplegata Paretas-Martínez and Pujade-Villar, 2007

-Margin of forewing continuous (Figure 1b). Antenna with cylindrical pedicel ...... 2

2. Visible metasoma represented by single tergal plate (Figure 1e). Antennae with 2 last flagellomeres broadly jointed or fused, preceding flagellomeres with constrictions between them (Figure 1c) .....

\section{(Dilyta Förster, 1869) 3}

- Visible metasoma with 2 large terga of subequal dorsomedian length (Figure 1f). All flagellomeres of antennae separated by constrictions (Figure 1d) .................... 7

3. Distal $1 / 2$ of metasoma with punctate area 4

- Distal 1/2 of metasoma without punctate area or at most with very few scattered, indistinctly visible punctures

4. F1 subequal or slightly longer than pedicel; F1 shorter or subequal to F2+F3 combined

D. longinqua Paretas-Martínez and Pujade-Villar, 2011

- F1 very long, almost twice as long as pedicel; F1 longer than F2+F3 combined ...... 5

5. Only females known. F1 thin; F1 nearly as long as $\mathrm{F} 2+\mathrm{F} 3+\mathrm{F} 4$ combined

D. japonica Paretas-Martínez and Ferrer-Suay, 2011

- Only males known. F1 wide, arched

D. sinica Ferrer-Suay and Paretas-Martínez, 2011

6. Female: F1 narrow; F2 slightly shorter or subequal to F3; F4 longer than F2 and F3 respectively; antennae slightly clavate from F6. Male unknown ..... D. orientalis Ferrer-Suay and Paretas-Martínez, 2011 
- Female: F1 not narrow; F2 slightly longer than F3 and F4 respectively; F3 subequal to F4; antenna slightly clavate from F5. Male: F1 longer than pedicel and slightly arched; F1 longer than F2 and F3; F2 subequal to F3; F3 shorter than F4; F4-F12 wider than previous segments, antenna slightly clavate from F4; sensilla beginning on F6 D. aleevae

Pujade-Villar and Paretas-Martínez, 2011

7. Lower part of mesopleuron with horizontal sulcus (Figure 1g)

Förster, 1869) 8

(Phaenoglyphis

- Mesopleuron without horizontal sulcus (Figure 1h) (Alloxysta Förster, 1869) 17

8. Mesoscutum (except mesopleura) covered by imbricate sculpturing

(Förster, 1869)

P. ruficornis

- Mesoscutum smooth, without imbricate sculpturing 9

9. Radial cell open or partially open 10

- Radial cell closed .. 13

10. Radial cell completely open; notauli present

Pujade-Villar sp. nov.

- Radial cell partially open; notauli absent

11. Scutellar foveae present; pronotum and mesoscutum with scattered setae.

(Hartig, 1841)

P. villosa

- Scutellar foveae absent; pronotum and mesoscutum covered by abundant pubescence.

12

12. Rhinaria and club-shape beginning in F2; radial cell 2.6-times as long as wide P. asiatica Ferrer-Suay

and Pujade-Villar sp. nov.

- Rhinaria and club-shape beginning in F3; radial cell 3.8-times as long as wide

and Pujade-Villar sp. nov.

P. chinensis Ferrer-Suay

13. Head, mesosoma, and metasoma yellowish-brown; Female: F2 shorter than F3, F3 and F4 subequal in length; notauli deeply excavated; scutellar foveae rounded but with straight interior side; radial cell 2.5times as long as wide. Male: F2 F4 subequal in length, F1 curved..... P. xanthochroa Förster, 1869

- Head, mesosoma, and metasoma dark-brown; different proportions between flagellomeres in male and female when they are known; different sizes of radial cell.
14. Antennae shorter than or subequal to body length; rhinaria and club-shape beginning in F3; oval scutellar foveae, anterior and posterior margins not clearly defined. Male unknown $P$. japonica

Ferrer-Suay and Pujade-Villar sp. nov.

- Antennae longer than body length; rhinaria and club-shape beginning in F1; scutellar foveae of different shapes; 2 thin carinae joining at base .. 15

15. Rhinaria and club-shape beginning on all F1; F2 subequal to F3, and F3 shorter than F4; scutellar foveae with straight top and side, open at bottom; radial cell 2.7-times as long as wide; Rs slightly curved. Male unknown P. longicornis (Hartig, 1840)

- Rhinaria and club-shape on last 3/4 of F1; different proportions between flagellomeres; different shapes of scutellar foveae; different sizes of radial cells; Rs straight .. 16

16. Last flagellomere 2.5-times as long as wide; mesoscutum with abundant setae on lateral and anterior margins; scutellar foveae with straight sides and open at top and bottom; propodeum with 2 straight, parallel carinae, reaching base independently; radial cell 2.4-times as long as wide. Male unknown

P. stricta (Thomson, 1877)

- Last flagellomere 4.3-times as long as wide; mesoscutum with a line of setae next to each notaulus; scutellar foveae rounded, slightly open at bottom; propodeum with 2 long, straight, parallel carinae joining at base; radial cell 2.9-times as long as wide. Male unknown P. insperata

Belizin, 1973

17. Radial cell closed 18

- Radial cell open or partially open ..................... 26

18. Pronotal carinae absent (Figure 3a); antennae shorter than or subequal to body length; F1 shorter than pedicel, F1 F3 subequal in length (Figure 2b); radial cell 2.1-times as long as wide (Figure $5 \mathrm{~b})$.......................... Arevis (Thomson, 1862)

- Pronotal carinae present (Figure 3b); antennae longer than body length; different proportions between flagellomeres; different sizes of radial cells ......................... 19

19. Propodeal carinae absent (Figure 4b) .............. 20

- Propodeal carinae present (Figure 4a) ................. 21

20. Beginning of rhinaria in F3, F2-F4 subequal (Figure 2i); radial cell 3.0-times as long as wide (Figure $5 \mathrm{~h}$ ); propodeum without setae in longitudinal area where carinae are present in other Charipinae (Figure 4b) A. victrix (Westwood, 1833)

- Beginning of rhinaria in F4, F2 longer than F3, and F3 shorter than F4; radial cell 2.7-times as long as wide; propodeum completely covered with dense setae (Hartig, 1841)
A. fuscicornis 
21. F1 subequal to pedicel 22

- F1 longer than pedicel 23

22. Antennae shorter than body length; beginning of rhinaria in F5 in female (Figure 2g) and F4 in male, male with no curved flagellomere; propodeal carinae narrow and well-defined in 1 st $1 / 2$, wide and forming a plate in 2nd $1 / 2$ with sharp edges A. sawoniewiczi (Kierych, 1988)

- Antennae longer than body length; beginning of rhinaria in F3 in female (Figure 2a) and F2 in male, F2 slightly curved in male; propodeal carinae forming a plate with few setae on top and sides slightly curved A. arcuata (Kieffer, 1902)

23. Male: rhinaria and club-shape beginning in F1; F2 and F3 curved; 2 propodeal carinae thick and straight, reaching base independently. Female unknown

\section{(Ashmead, 1904)}

A. japonica

- Male: rhinaria and club-shape not beginning in F1; F2 and F3 not curved or slightly curved; propodeal carinae forming a plate. Female known with different features......................... 24

24. Radial cell 2.9-times as long as wide in female (Figure 7a) and 2.7-times in male (Figure 7b); antennae much longer than body (Figure 7d); male with no curved flagellomere (Figure 7e) A. nepalica Ferrer-Suay and Pujade-Villar sp. nov.

- Radial cell < 2.9-times as long as wide in female and 2.7-times in male; antennae longer than body but not by much; male with any of F1-F3 curved 25

25. Radial cell 2.1-times as long as wide in female and 2.4-times in male (Figure 5e); F1-F3 slightly curved in male; propodeal carina with curved sides (Figure 4a)

A. pusilla (Kieffer, 1902)

- Radial cell 1.8-times as long as wide in both male and female (Figure 5g); only F3 slightly curved in male: propodeal carinae with almost-straight sides

26. Radial cell partially open A. tscheki (Giraud, 1860)

- Radial cell completely open 27

27. Propodeal carinae absent 36

- Propodeal carinae present

28. Female: beginning of rhinaria in F1, F1 longer than F2 F2 F4 subequal in length (Figure 12e); radial cell 2.9- times as long as wide (Figure 12b). Male unknown ....

and Pujade-Villar sp. nov.

A. sharkeyi Ferrer-Suay

- Female: beginning of rhinaria in F3, different proportions between flagellomeres; different sizes of radial cell ....................................................... 29

29. Female: F1 subequal to F2, F2 longer than F3, F3 subequal to $\mathrm{F} 4$; radial cell 3.0 -times as long as wide. Male: beginning of rhinaria in F2; F2 and F3 clearly curved A. macrophadna (Hartig, 1814)
- Female: F1 longer than F2, F2 F4 subequal in length; radial cell 2.5 -times as long as wide. Male: beginning of rhinaria in F4; with no curved flagellomeres . A. ullrichi

(Giraud, 1860)

30. Propodeal carinae not protruding; F1 subequal to pedicel in both male and female; rhinaria and club-shape beginning in F4; radial cell 2.1-times as long as wide ..........

(Thomson, 1862)

- Propodeal carinae well-defined and slightly protruding; without the above combination of features present .......................................... 31

31. Propodeum with 2 thick, well-defined carinae, reaching base independently and with curved sides; Rs almost straight; F1 F3 slightly curved in male

A. pleuralis (Cameron, 1879)

- Propodeum with 2 well-defined carinae in 1 st $1 / 2$ and joining at the base or 2 carinae forming a complete plate; Rs curved or slightly curved; F1-F3 not curved in male .................................................. 32

32. Antennae shorter than or subequal to body length. Female: beginning of rhinaria in F3, F3 shorter than F4 (Figure 6d). Male: beginning of rhinaria in F2, F1 shorter than pedicel, F1-F4 subequal in length. Well-defined propodeal carinae separated by abundant setae, joining at base; with a thick carina on apex of scutellum (Figure 6f); radial cell 2.2-times as long as wide (Figure 6b) A. asiatica Ferrer-Suay and Pujade-Villar sp. nov.

-Antennae longer than body; male and female with different proportions of flagellomeres; propodeal carinae forming a plate; without carinae on apex of scutellum; radial cell bigger than 2.2-times as long as wide ... 33

33. Female: pedicel and F3 subequal in length (Figure 2d). Male F1 longer than pedicel and F2, F2 subequal to F3. Beginning of rhinaria in F3 in both male and female (Figure 2d). Radial cell 2.0-times as long as wide ........... A. melanogaster (Hartig, 1840)

- Different proportions of flagellomeres in both male and female; beginning of rhinaria in F3 or F4; radial cell larger than 2.0-times as long as wide. ..................... 34

34. Beginning of rhinaria in F3 in female (Figure 2e) and F4 in male. Female: F2 shorter than F3 (Figure 2e). Male: F2 longer than F3, F2 slightly curved. Radial cell 2.7-times as long as wide (Figure 5d) ...... A. obscurata (Hartig, 1840)

- Beginning of rhinaria in F4 in both male and female (Figure 2c). Male and female with different proportions of flagellomeres, male with no curved flagellomere. Radial cell not 2.7-times as long as wide. ........................ 35

35. Male and female: F2 subequal to F3 (Figure 2c). Radial cell 2.4-times as long as wide (Figure 5c). A. castanea (Hartig, 1841) 
- Female: F2 shorter than F3; radial cell 3.0-times as long as wide. Male unknown

A. aurata Belizin, 1968

36. Propodeal carinae absent 37

- Propodeal carinae present 40

37. Body entirely covered by abundant setae (more abundant in female than male) (Figure 10c); radial cell very long, 4.9-times as long as wide in female (Figure 10a) and 3.2-times in male (Figure 10b) ....

A. pilosa Ferrer-Suay and Pujade-Villar sp. nov.

- Body covered with sparse setae; radial cell < 4.9times as long as wide in female and < 3.2-times in male 38

38. Pronotal carinae absent ... A. proxima Belizin, 1962

- Pronotal carinae present 39

39. Rhinaria and club-shape beginning in F4, F1 longer than F2, F2 subequal to F3, and F3 shorter than F4; radial cell 2.3-times as long as wide in female (Figure $8 \mathrm{~b}$ ). Male unknown A. nippona Ferrer-Suay and Pujade-Villar sp. nov.

- Rhinaria and club-shape beginning in F3 in female and F4 in male; F1-F4 subequal in male and female, F1 of male modified with a lateral hump; radial cell 3.0-times as long as wide in male and female ....

\section{........ A. mara Paretas-Martínez and Pujade-Villar, 2005}

40. Female: beginning of rhinaria in F2, F1 4.1-times as long as wide, F2-F4 subequal in length; radial cell 2.6times as long as wide. Male: beginning of rhinaria in F1, F2 slightly curved A. pallidicornis (Curtis, 1838)

- Female: beginning of rhinaria in other flagellomeres, different proportions between flagellomeres; different sizes of radial cells. Male unknown .. .41

41. Female: beginning of rhinaria in F4, F1 shorter than pedicel, F1 longer than F2, F2 shorter than F3, F3 shorter than F4 (Figure 11d); propodeal carinae well-defined in 1 st $2 / 3$ and narrow, thick at base and reaching it independently; with thick and parallel carinae on apex of scutellum (Figure 11f); radial cell 2.8-times as long as wide (Figure 11b) ........................ A. samurai Ferrer-Suay and Pujade-Villar sp. nov.

- Female: beginning of rhinaria in F3, different proportions between flagellomeres; different shapes of propodeal carinae; different sizes of radial cells 42

42. Propodeal carinae well-defined and thick, reaching base independently, with slightly curved sides; with few wrinkles on apex of scutellum (Figure 9f)

A. paretasmartinezi Ferrer-Suay and Pujade-Villar sp. nov.

- Propodeal carinae forming a plate with slightly curved sides; without carinae on apex of scutellum A. xanthopa (Thomson, 1862)

\section{Authors' contributions}

MFS was responsible for the initial drafting of the manuscript. JS and JPV, directors of the thesis of MFS, have been responsible for the corrections of the manuscript before it was being sent to the journal. All authors have participated in the discussion of the manuscript. All authors read and approved the final manuscript.

\section{Acknowledgements}

We are very grateful to J. Huber, G. Gibson, and J. Read (CNCl) for the loan of the material studied in this work. We also want to thank E. Rakhshani for sending us the material collected in India. This research was supported by projects CGL200800180 and CGL2011-22889 of the Ministerio de Ciencia e Innovación (Spain) and grant AP2009-4833 of the Ministerio de Educación (Spain).

\section{Author details}

${ }^{1}$ Departament de Biologia Animal, Facultat de Biologia, Universitat de Barcelona, Avda. Diagonal 645, Barcelona 08028, Spain. ²Departament de Zoologia, Facultat de Ciències Biològiques, Universitat de València, Campus de Burjassot-Paterna, Dr. Moliner 50, Burjassot, Valencia 46100, Spain.

Received: 13 September 2012 Accepted: 19 March 2013

Published: 12 November 2013

\section{References}

Ahmad ME, Singh R (1996) Records of aphid parasitoids from the Bihar and associations with their hosts and food plants. J Adv Zool 17:26-33

Al-Jassani RF, Al-Adil KM (1986) Insect enemies of the black bean aphid Aphis fabae Scop. in Abu-Graib. J Biol Sci Res 48:812-813

Argaman Q (1988) Additions to the Cynipoid fauna of Israel (Hymenoptera, Cynipoidea). Isr J Entomol 22:109-117

Dessart P (1969) Les types de Cynipidae décrits par l'abbé Jean-Jaques KIEFFER, conservés dans la collection Léon CARPENTIER au Musée d'Histoire naturelle d'Amiens (France). Bull Ann Soc R Entomol Belg 105:180-201

Ferrer-Suay M, Paretas-Martínez J, Selfa J, Pujade-Villar J (2012) Taxonomic and synonymic world catalogue of the Charipinae and notes about this subfamily (Hymenoptera: Cynipoidea: Figitidae). Zootaxa 3376:1-92

Ferrer-Suay M, Selfa J, Seco-Fernández MV, Melika G, Alipour A, Rakhshani E, Talebi AA, Pujade-Villar J (2013) Contribution to the knowledge of Charipinae from Iran (Hymenoptera: Cynipoidea: Figitidae) associating with aphids (Hemiptera: Aphididae), including new records. North-West J Zool 9(1):30-44

Fülop F, Mikó I, Seltmann K, Pénzes Z, Melika G (2013) The description of Alloxysta chinensis, a new Charipinae species from China (Hymenoptera, Figitidae). Zootaxa 3637(3):394-400

Lotfalizadeh H (2002a) Natural enemies of cotton aphids in Moghan Region, northwest of Iran. In: Proceedings of 15th Iranian Plant Protection Congress, 7-11 Sept. 2002, vol Ith edn. Razi University of Kermanshah, Pests, p 36

Lotfalizadeh H (2002b) Parasitoids of cabbage aphid, Brevicoryne brassicae (L.) (Hom.: Aphididae) in Moghan Region. Agric Sci 12:15-25

Lotfalizadeh H, van Veen F (2004) Report of Alloxysta fuscicornis (Hym.: Cynipidae), a hyperparasitoid of aphids in Iran. J Entomol Soc 23:119-120

Paretas-Martínez J, Arnedo MA, Melika G, Selfa J, Seco-Fernández MV, Fülöp D, Pujade-Villar J (2007) Phylogeny of the parasitic wasp subfamily Charipinae (Hymenoptera, Cynipoidea, Figitidae). Zool Scr 36:153-172

Pujade-Villar J, Paretas-Martínez J, Selfa J, Secó-Fernández MV, Fülop D, Melika G (2007) Phaenoglyphis villosa (Hartig 1841) (Hymenoptera: Figitidae: Charipinae): a complex of species or a single but very variable species? The Annales de la Société Entomologique de France 43(2):169-179

Pujade-Villar J, Ferrer-Suay MM, Selfa J, Caicedo-Ramírez G (2010) Primera Cita de ChariinaE (Hym., Figitidae) para Colombia. Boletín del Museo de Entomología de la Universidad del Valle 11(2):28-32

Takada H, Nakamura T (2010) Native primary parasitoids and hyperparasitoids attacking an invasive aphid Uroleucon nigrotuberculatum in Japan. Entomol Sci 13:269-272

doi:10.1186/1810-522X-52-41

Cite this article as: Ferrer-Suay et al.: Charipinae fauna (Hymenoptera: Figitidae) from Asia with a description of 11 new species. Zoological Studies 2013 52:41. 